\title{
Differential expression of members of the E2F family of transcription factors in rodent testes Kame S El-Darwish ${ }^{* 1}$, Martti Parvinen ${ }^{2}$ and Jorma Toppari ${ }^{1}$
}

Address: ${ }^{1}$ Departments of Physiology and Pediatrics, University of Turku, Kiinamyllynkatu 10, FIN- 20520, Turku, Finland and ${ }^{2}$ Department of Anatomy, University of Turku, Kiinamyllynkatu 10, FIN- 20520, Turku, Finland

Email: Kame S El-Darwish* - kdarwish@saunalahti.fi; Martti Parvinen - marparvi@utu.fi; Jorma Toppari - jortop@utu.fi

* Corresponding author

Published: 05 December 2006

Reproductive Biology and Endocrinology 2006, 4:63 doi:10.1/86/1477-7827-4-63

This article is available from: http://www.rbej.com/content/4/I/63

(c) 2006 El-Darwish et al; licensee BioMed Central Ltd.

This is an Open Access article distributed under the terms of the Creative Commons Attribution License (http://creativecommons.org/licenses/by/2.0), which permits unrestricted use, distribution, and reproduction in any medium, provided the original work is properly cited.

\begin{abstract}
Background: The E2F family of transcription factors is required for the activation or repression of differentially expressed gene programs during the cell cycle in normal and abnormal development of tissues. We previously determined that members of the retinoblastoma protein family that interacts with the E2F family are differentially expressed and localized in almost all the different cell types and tissues of the testis and in response to known endocrine disruptors. In this study, the cell-specific and stage-specific expression of members of the E2F proteins has been elucidated.
\end{abstract}

Methods: We used immunohistochemical $(\mathrm{IHC})$ analysis of tissue sections and Western blot analysis of proteins, from whole testis and microdissected stages of seminiferous tubules to study the differential expression of the E2F proteins.

Results: For most of the five E2F family members studied, the localizations appear conserved in the two most commonly studied rodent models, mice and rats, with some notable differences. Comparisons between wild type and E2F-I knockout mice revealed that the level of E2F-I protein is stage-specific and most abundant in leptotene to early pachytene spermatocytes of stages IX to $\mathrm{XI}$ of mouse while strong staining of E2F-I in some cells close to the basal lamina of rat tubules suggest that it may also be expressed in undifferentiated spermatogonia. The age-dependent development of a Sertoli-cell-only phenotype in seminiferous tubules of E2F-I knockout males corroborates this, and indicates that E2F-I is required for spermatogonial stem cell renewal. Interestingly, E2F-3 appears in both terminally differentiated Sertoli cells, as well as spermatogonial cells in the differentiative pathway, while the remaining member of the activating E2Fs, E2F-2 is most concentrated in spermatocytes of mid to late prophase of meiosis. Comparisons between wildtype and E2F-4 knockout mice demonstrated that the level of E2F-4 protein displays a distinct profile of stage-specificity compared to E2F-I, which is probably related to its prevalence and role in Sertoli cells. IHC of rat testis indicates that localization of E2F-5 is distinct from that of E2F-4 and overlaps those of E2F-I and E2F-2.

Conclusion: The E2F-I represents the subfamily of transcription factors required during stages of DNA replication and gene expression for development of germ cells and the E2F-4 represents the subfamily of transcription factors that help maintain gene expression for a terminally differentiated state within the testis. 


\section{Background}

The testis provides an exceptional system for studying fate determination, differentiation, and death (apoptosis), interposed on mitosis and meiosis, and all these intertwined processes occurring in a single population of cells. The stages or fixed groups of cells undergoing different phases of spermatogenesis develop as a wave along the seminiferous tubule, continuously cycling over time.
Spermatogonial stem cells are supposedly "awakened" from a quiescent state by signals such as glial cell linederived neurotrophic factor (GDNF), and subsequent path selection maybe determined by the ratio of follicle stimulating hormone (FSH) to GDNF favoring differentiation over renewal, respectively [Fig. 1, adapted from [1]]. Subsequently, and concurrent with proliferation of type A spermatogonia committed to differentiation, stem cell

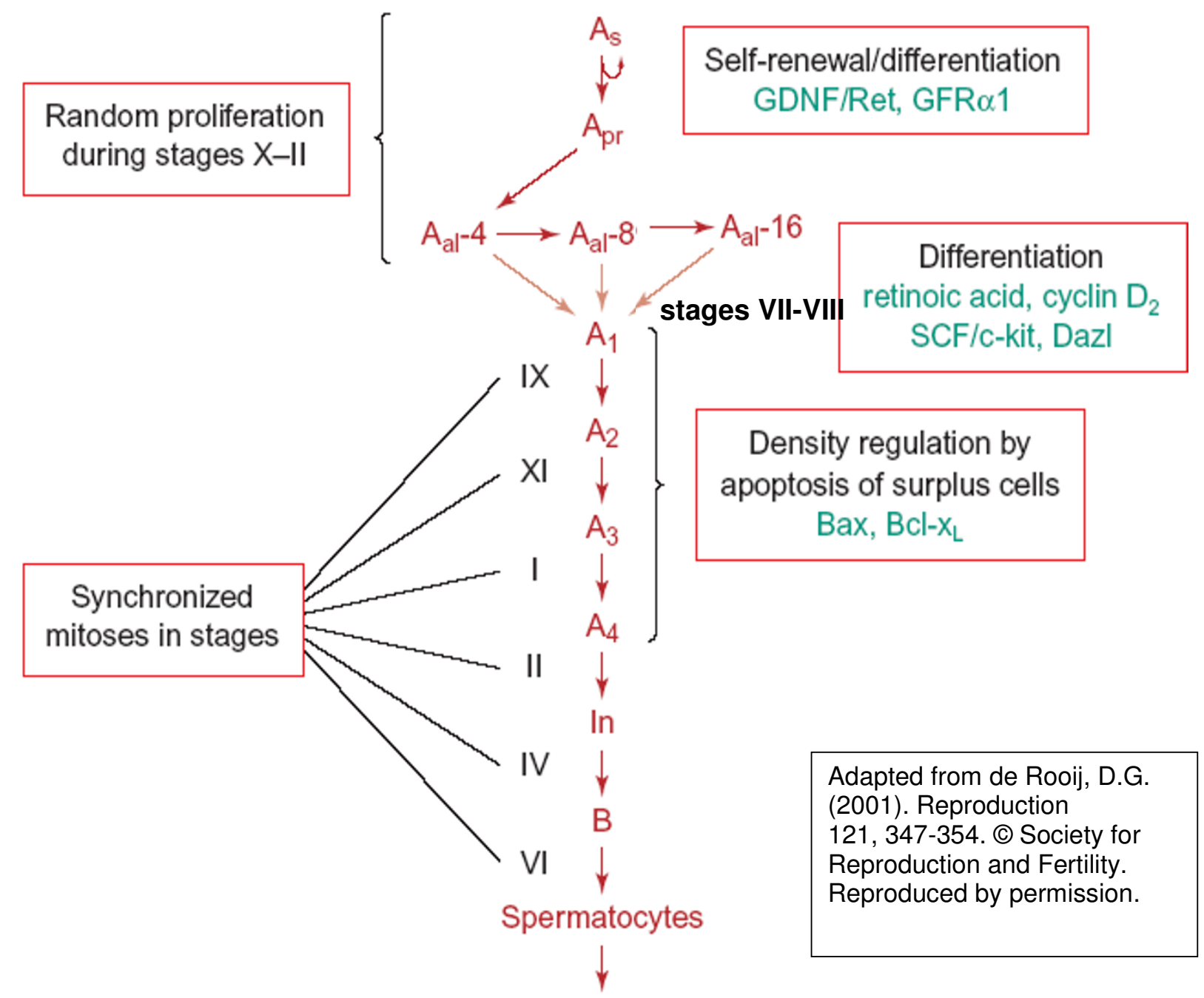

\section{Figure I}

Stage-specificity of spermatogonial renewal, proliferation, differentiation, and its regulation, as reviewed by Dirk G. de Rooij [I]. Abbreviations: $A_{s}=$ spermatogonial stem cell, $A_{p r}=$ paired spermatogonia, $A_{a l}-n=$ aligned spermatogonia of $n$ number of cells, $A_{n}=$ differentiated type $A$ spermatogonia entering synchronised division number $n, \ln =$ intermediate type spermatogonia, $\mathrm{B}=\mathrm{B}$-type spermatogonia which undergo final mitotic division before replication and division for Meiosis I, GDNF/Ret are the ligand/receptor tyrosine kinase complex for glial cell-line derived neurotrophic factor (GDNF) signaling, GFR $\alpha$ is the glycosylphosphatidylinositol (GPI)-achored coreceptor for GDNF/Ret, SCF/c-kit are the ligand/receptor complex for stem cell factor (SCF) signaling, Dazl is the deleted in azoospermia-like gene, and Bax and Bcl- $\mathrm{X}_{\mathrm{L}}$ are pro-apoptopic and anti-apoptopic Bcl-2 protein family members respectively. 
factor (SCF) and retinoic acid are critical for survival and differentiation. Mitotic division and orientation away from the basement membrane, i.e. asymmetric mitosis, is also suggested to influence commitment to differentiation inasmuch as at least one daughter of an asymmetric mitotic division would be shifted away from the stem cell niche and towards the lower concentration of a gradient of signals, e.g. desert hedgehog, that repress differentiation [2]. Finally, in adult males, wherein the number of terminally differentiated Sertoli cells capable of supporting spermatogenesis has been established, normal sperm production, estimated at 1000/second in human [3], depends on the tight regulation of active proliferation, differentiation, and death [4].

The retinoblastoma protein $(\mathrm{pRb})$ and related proteins p107 and p130 are key mediators of cell cycle arrest, differentiation, proliferation, senescence, and apoptosis, in response to a wide variety of signals. They fulfill their central role by interacting with a multitude of other proteins. The retinoblastoma protein is thought to interact with over 110 different partners [5], including transcription factors, to regulate the expression of genes affecting a cell's state of quiescence or differentiation, cycles of replication and division in active proliferation, or death. Most notable amongst $\mathrm{pRb}$ partners are the members of the E2F family of transcription factors. Different pRbs have preferential binding partners of the E2F family, and the expression of both partners is dependent on the stage of the cell cycle [6]. The pRbs are themselves tightly regulated by posttranslational modifications, especially phosphorylation at specific threonines and serines, catalyzed by cyclin dependant kinases (CDKs), which are regulated by cyclins. The levels of G1 cyclin D can be increased transcriptionally, translationally, or postranslationally by kinasedriven signal transduction pathways, which are activated upstream by signals that a cell receives, often referred to as the "context" of a cell. FSH and SCF are two of the key signals known to affect the differentiation of young (type A) spermatogonia, and both are known to affect an increase in cyclin D levels $[7,8]$. Since $\mathrm{pRb}$ is the principal substrate for cyclin D regulated CDKs 4 and 6, which initiate phosphorylation of $\mathrm{pRb}$ and its release of E2Fs 1-4, it is expected that the dynamic control of gene expression programs of spermatogenesis dependent on FSH and SCF be driven through interactions between the $\mathrm{pRb}$ and $\mathrm{E} 2 \mathrm{~F}$ families.

Our previous study of the retinoblastoma family of proteins (henceforth abbreviated pRbs) revealed differential expression and localization in the testis, indicating specialized roles for these cell cycle regulators and their partners in the development and maintenance of testis in rats $[9,10]$. Interestingly, the stage-specific expression pattern of $\mathrm{pRb}$ in Sertoli cells (highest at stages VII-VIII) disap- pears during days 2-20 after ethylene-dimethane sulfonate (EDS) treatment when testosterone levels are undetectable, suggesting that $\mathrm{pRb}$ levels can be affected by androgens. The level and phosphorylation status of p130 correlated with Leydig cell apoptosis: during the first days after EDS treatment, when massive Leydig cell apoptosis occurs, the level of p130 decreased and it became hypophosphorylated. Knockout mice have been invaluable to studies directed at determining the true biological roles of the pRbs, but reports of testis phenotypes have been conspicuously lacking. In contrast, knockout of E2F-1 produced testicular atrophy [11] with a Sertoli-cell-only (empty tubules) phenotype, and the addition of a hemizygous E2F-3 knockout to a full knockout of E2F-1 accelerates the development of testicular atrophy [12], even though knockout of E2F-3 alone exerts no effect on testis. This exacerbated phenotype in the compound or double knockout (DKO) suggested overlap in the biological roles of E2F-1 and E2F-3 in the testis. A knockout of an atypical member of the family, E2F-6, also generated a testis phenotype, manifesting Leydig cell hyperplasia and incomplete filling of epididymal ducts [13]. Knockout of E2F-4 causes infertility in both sexes, though the gonads appeared histologically normal $[14,15]$. These knockouts expressing testis phenotypes and the knockout of E2F-5 [16] and E2F-2 [17], which generated hydrocephaly and autoimmune phenotypes, respectively, underscore the critical role of E2Fs in regulating gene expression programs necessary for normal tissue differentiation and organogenesis. The study described herein was initiated in order to determine how the retinoblastoma and E2F families might interact to control the maintenance of testicular tissue organization, and the entry of undifferentiated quiescent spermatogonial cells into the mitotic proliferation leading to meiosis and differentiation into spermatozoa. The cell- and stage-specific localization of E2Fs in the testis from the study herein, compared to our previously developed map of the pRbs in testis $[9,10]$, correlates with traditional paradigms of partnerships between different family members and their roles in regulating the expression of programs of genes required for active proliferation versus differentiation. However, some of our results may also suggest a more independent role for certain members or unexpected partnerships between these two protein families.

\section{Materials and methods}

The E2F-1 -/- mice [18], B6;129S4-E2f1tm1Meg/J, and control mice (B6129SF2/J) were purchased from the Jackson Laboratory. Patrick Humbert generously provided the E2F-4 -/- mice [14] and E2F-5/mice [16]. FVB/N mice were obtained from breeding stocks of the Transgenic Core Facility and Sprague-Dawley rats were obtained from breeding stocks of the Central Animal Laboratory of the University of Turku. All procedures performed on animals 
were in strict accordance with the European Convention for the Protection of Vertebrate Animals used for Experimental and other Scientific Purposes (ETS No.123), Appendix A: Guidelines for accommodation and care of animals, and the European Union Directive 86/609/ETY on the protection of animals used for experimental and other scientific purposes.

For the immunohistochemical analysis of E2Fs, sections of paraformaldehyde-fixed and paraffin-embedded (FFPE) testis were deparaffinized and rehydrated as described elsewhere [19]. For antigen retrieval, slides were incubated in $10 \mathrm{mM}$ citrate buffer $\mathrm{pH} 6.0$ heated to boiling in a microwave oven, for ten minutes $[20,21]$. Staining with primary monoclonal antibodies, counterstaining with horseradish peroxidase (HRP)-conjugated antimouse IgG secondary antibody, and the staining with peroxidase substrate were performed using the PowerVision+ and Homomouse IHC kits and protocols from ImmunoVision Technologies, Co. The primary antibodies used for immunohistochemistry were mouse monoclonal antibodies (MAbs) of the same immunoglobulin isotype and light chain against E2F-1, E2F-2 and E2F-4, and a synthetic hapten which is normally not present animals (negative control) purchased from Lab Vision Corporation, a mouse monoclonal antibody against E2F-3 from Upstate, a mouse monoclonal antibody against E2F-5 from Santa Cruz Biotechnology, Inc., rabbit polyclonal antibodies against p107, SMADs (small mothers against decapentaplegic) $1 / 2 / 3$, SMAD 4 and androgen receptor (positive control) from Santa Cruz Biotechnology, Inc., and a rabbit polyclonal antibody against a synthetic hapten which is normally not present in animals (negative control) from Lab Vision Corporation. Staining with negative control antibodies was always performed with at least the same dilution as the least dilute test antibody. Immunohistochemistry results were collated from repeated analyses of sections of testis from at least three individuals of each species, rat and mouse testes sections stained at the same time, and sections of testes from at least three pairs of littermates or age-matched (8 weeks or older) individuals of wild type and knockout mice from each line stained at the same time. The primary antibodies used for Western blot analyses were MAbs against E2F-1 and E2F4 from Lab Vision Corporation, a MAb against E2F-4 provided by Jacqueline Lees, and a MAb against glyceraldehyde-3-phosphate dehydrogenase (GAPDH) from HyTest Ltd. The HRP-conjugated secondary antibodies used in Western blot analysis were purchased from Amersham Biosciences.

Segments containing defined stages of mouse seminiferous tubule were microdissected from the testis of adult animals, on a transilluminating stereomicroscope [22] and flash-frozen in liquid nitrogen. Total proteins were extracted by homogenizing frozen tubules directly into an extraction buffer (Cell Cycle Methods booklet 4, Biosource International) containing a cocktail of protease inhibitors (complete Mini, from Roche Diagnostics $\mathrm{GmbH}$ ) and activated orthovanadate (protocol from Upstate), briefly vortexing to facilitate thawing, and passaging 6-8 times through a $25 \mathrm{G} 5 / 8$ " needle using a $1 \mathrm{ml}$ syringe. The resulting extracts were incubated at room temperature for $15 \mathrm{~min}$, before centrifugation at $16000 \mathrm{~g}$ for $4^{\circ} \mathrm{C}$. Then the extracts were kept on ice if the concentrations of protein were to be determined right away or flash-freeze in liquid nitrogen before storing at $-80^{\circ} \mathrm{C}$. The concentrations of protein in different extracts were quantitated by bicinchoninic acid (BCA) assay from Pierce. One hundred micrograms samples of the protein extracts were resolved through sodium dodecyl sulfate polyacrylamide gel electrophoresis (SDS-PAGE), with a $4 \%$ acrylamide stacking gel and $8 \%$ acrylamide resolving gel. Western transfer to a polyvinylidene fluoride (PVDF) membrane was performed as described elsewhere [23], except that ethanol was used in place of methanol in the transfer buffer. After immunostaining with primary and secondary antibodies, bands were detected on blots by treatment for enhanced chemiluminescent (ECL) detection with the enhanced ECL plus kit (Amersham-Biosciences) and exposure on Fuji Rx $100 \mathrm{X}$-ray film. The level of GAPDH protein, i.e. stained band intensity, was used as a control on immunostained Western blots, for quantitation of total proteins by BCA assay, and for loading and transfer of total proteins in SDS-PAGE and electrophoretic transfer.

The developed films were scanned on a UMAX Astra $2000 \mathrm{U}$ and densitometric analysis of specific bands was performed with the Image $\mathrm{J}(1.37 \mathrm{u})$ software by Wayne Rasband, the National Institutes of Health, USA. Data from at least three independent experiments were processed for statistical analysis of variance (ANOVA) for repeated measures by the WINKS 4.80 a software from TexaSoft, USA. Using the Newman-Keuls multiple comparisons test, the means of relative levels of E2F for different pooled stage(s) were not considered significantly different at the 0.05 significance level, while differences between the means were judged as significant at a p $<$ 0.025 , and plots of the means reflect these groupings.

\section{Results}

Localizations of E2F-I, E2F-2 and E2F-3

Staining for E2F-1 appears to be somewhat different for rat compared to mouse testis (Fig. 3), the IHCs have in common the staining of nuclei of spermatocytes from leptotene to early pachytene, most evident in stages XI to XI. The specificity of staining by the anti-E2F-1 MAb on wildtype mouse sections was established by simultaneously staining these sections alongside sections from an 
E2F-1 -/- (knockout) (Fig. 3), wherein hardly any staining is visible above that obtained for the negative control MAb (Fig. 2). Staining of rat sections with anti-E2F-1 also reveals some type $\mathrm{A} 3$ spermatogonia in stages XIII, as well as type A and intermediate type spermatogonia in stages II to V, and IX (Fig. 3, and Fig. 11). These observations from immunohistochemistry for E2F-1 are in concordance with the results from Western blot analyses that displayed a most distinct increase in the level of a $56 \mathrm{kDa}$ protein corresponding to E2F-1, which was absent from separated sample of E2F-1 knockout testis (data not shown), between stages VIII and IX of mouse (Fig. 16). E2F-2 is localized most abundantly in the nuclei of pachytene and diplotene spermatocytes of stages VII-XIII, but also lighter staining of secondary spematocytes at stage XIV of rat is apparent (Fig. 4 and Fig. 12). E2F-3 is most strongly stained in the nuclei of type A, intermediate and type $\mathrm{B}$ spermatogonia of stages II to $\mathrm{V}$ of rat, with lighter staining in Sertoli cells of other stages (Fig. 5, and Fig. 13). The antibody against E2F-3 stained Sertoli cells in mouse testis sections more strongly than on rat testis sections.

\section{Differential compartmentalization of E2F-4 and E2F-5}

The antibody against E2F-4 stained the nuclei of the somatic cells (Leydig, Sertoli and peritubular myoid cells) of the testis most strongly, and especially so the Leydig cells. However, parallel staining of testis sections from E2F-4 knockout mice demonstrated that only staining of Sertoli cells was absent (data not shown). The staining of Sertoli cells appears darker in stages IV to VI than in other stages (Fig. 6, and Fig. 14). The antibody used to detect E2F-5 in the rat testis, where it most intensely stained nuclei of type B spermatogonia, preleptotene and pachytene spermatocytes in stages from IV to VIII (Fig. 7, and Fig. 15) did not stain sections of wild type and E2F-5 knockout mouse testis specifically under any of the conditions tested, in parallel experiments. At higher magnification, staining of rat testis sections with anti-E2F-5 appears to display a perinuclear or diffuse cytoplasmic staining in zygotene spermatocytes of stage XIII to late pachytene of stage VII. Staining for p107 appears most prevalent in differentiating spermatogonia, and lesser in early spermatocytes in meiosis (Fig. 8), while stainings for SMADs $1 / 2 / 3$ (R-SMADs) and SMAD 4 (N-SMAD) revealed strongest localization of these in spermatogonia and spermatocytes up to the pachytene stage, but not beyond (Figures 9 and 10).

Western blot analyses demonstrated a $65 \mathrm{kDa}$ protein corresponding to E2F-4 (Paul Danielen, MIT, personal communication) present in samples extracted from wild type $(\mathrm{E} 2 \mathrm{~F}-4+/+)$ and heterozygous (E2F-4 +/-) mouse testis, but absent in protein samples from testis of E2F-4 knockout siblings, separated in parallel. The level of the E2F-4 band increased between stages VI and VII, and then plateaued over remaining stages of the seminiferous epithelium (Fig. 17). It was not possible to detect specifically E2F-5 protein in wild type compared to E2F-5 knockout mouse testis. Nevertheless, Western blot analyses of protein extracts from ten pooled stages of microdissected rat
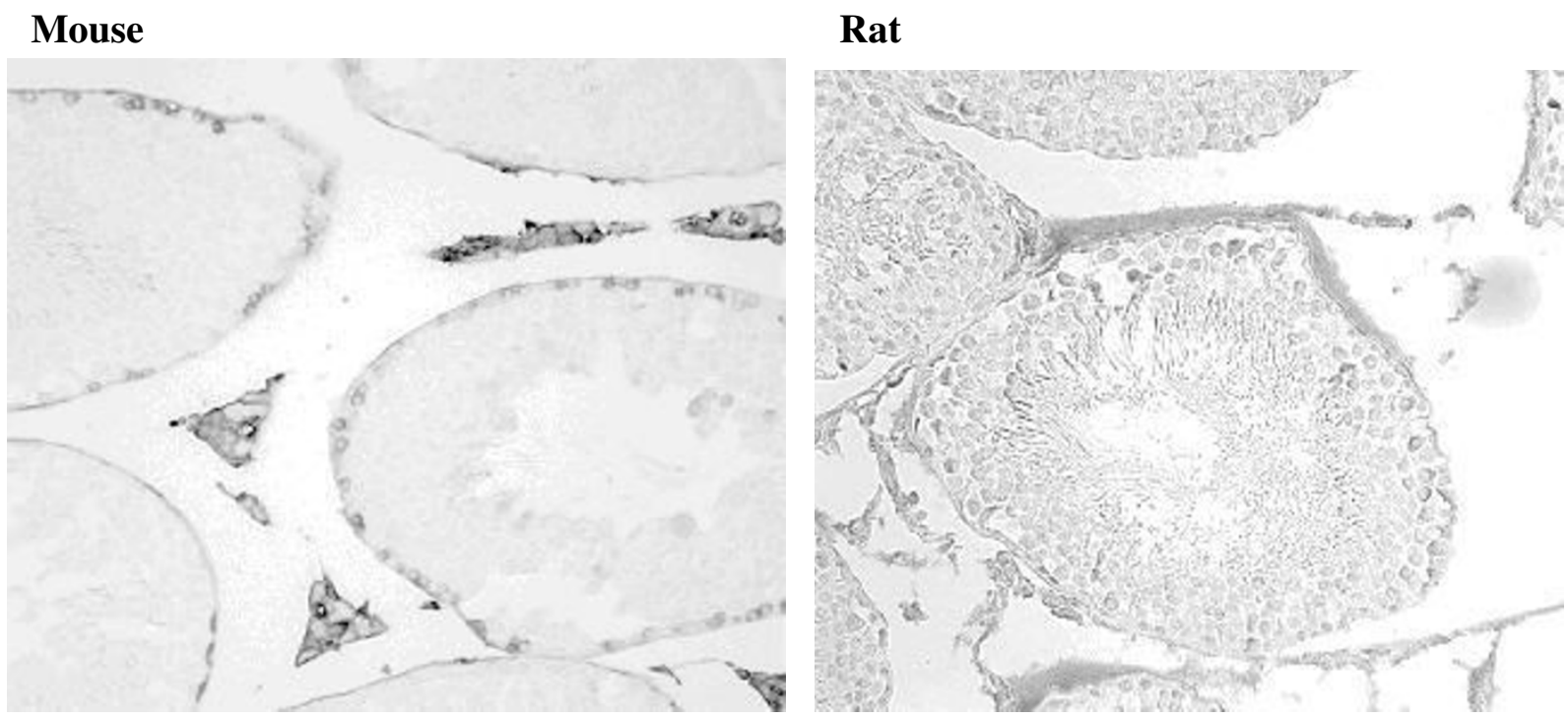

\section{Figure 2}

Immunohistochemical staining of sections from testis of mouse and rat with antibody against synthetic negative control peptide. 

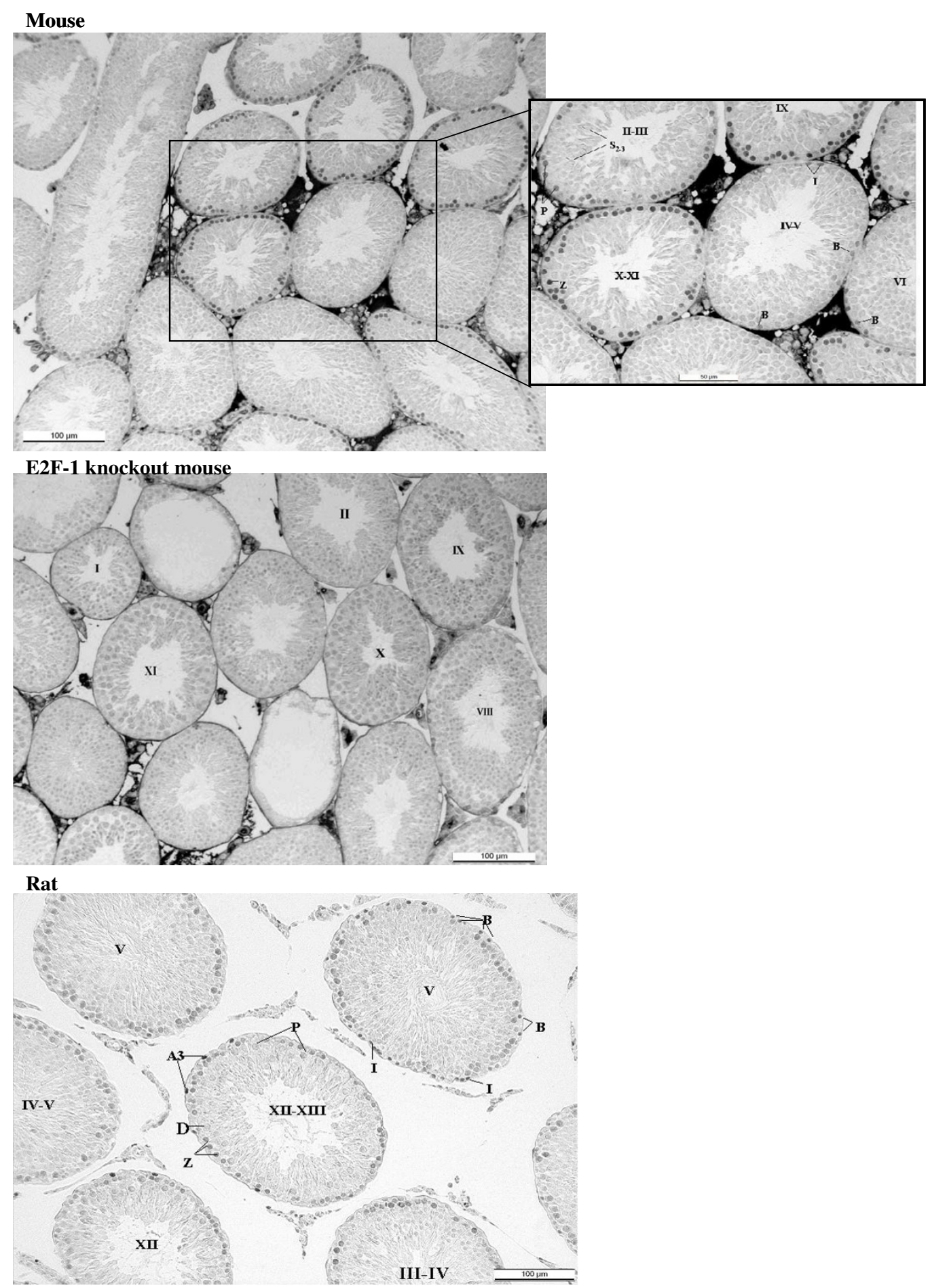

\section{Figure 3}

Immunohistochemical staining of sections from testis of mouse, E2F-I knockout mouse, and rat with antibody against E2F-I. Labels are: for germline type A spermatogonia (A), intermediate (I) and B-type (B) spermatogonia, preleptotene (PI), pachythene $(P)$, zygotene $(Z)$, and diplotene $(D)$ spermatocytes, spermatids (s), and for somatic Sertoli cell (S), Leydig cell (L), and peritubular myoid cell (M); stages indicated by Roman numerals I-XIV for rat and I-XII for mouse. 

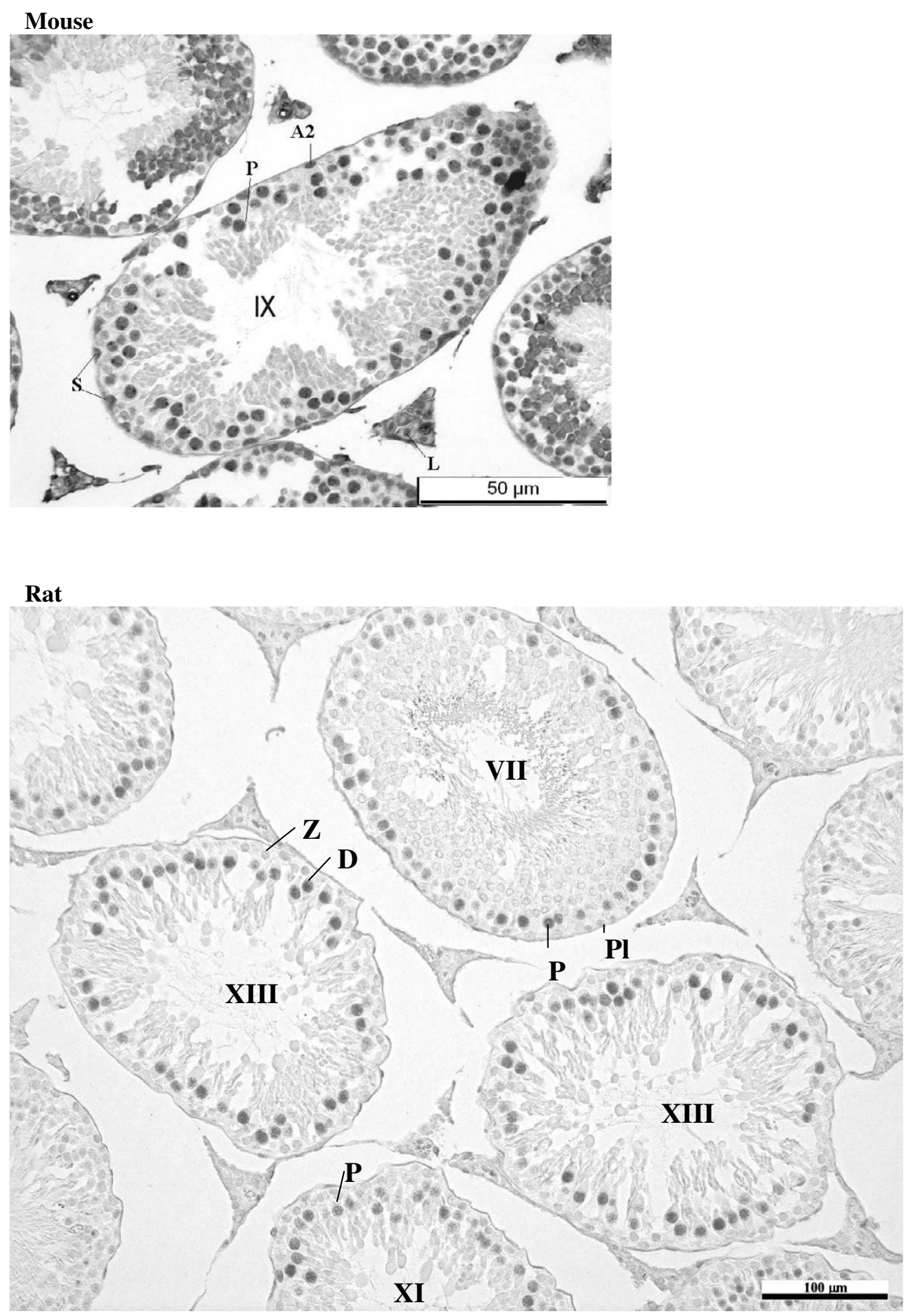

\section{Figure 4}

Immunohistochemical staining of sections from testis of mouse and rat with antibody against E2F-2. Labels are: for germline type A spermatogonia $(A)$, intermediate $(I)$ and $B$-type $(B)$ spermatogonia, preleptotene $(P I)$, pachythene $(P)$, zygotene $(Z)$, and diplotene (D)spermatocytes, spermatids (s), and for somatic Sertoli cell (S), Leydig cell (L), and peritubular myoid cell (M); stages indicated by Roman numerals I-XIV for rat and I-XII for mouse. 

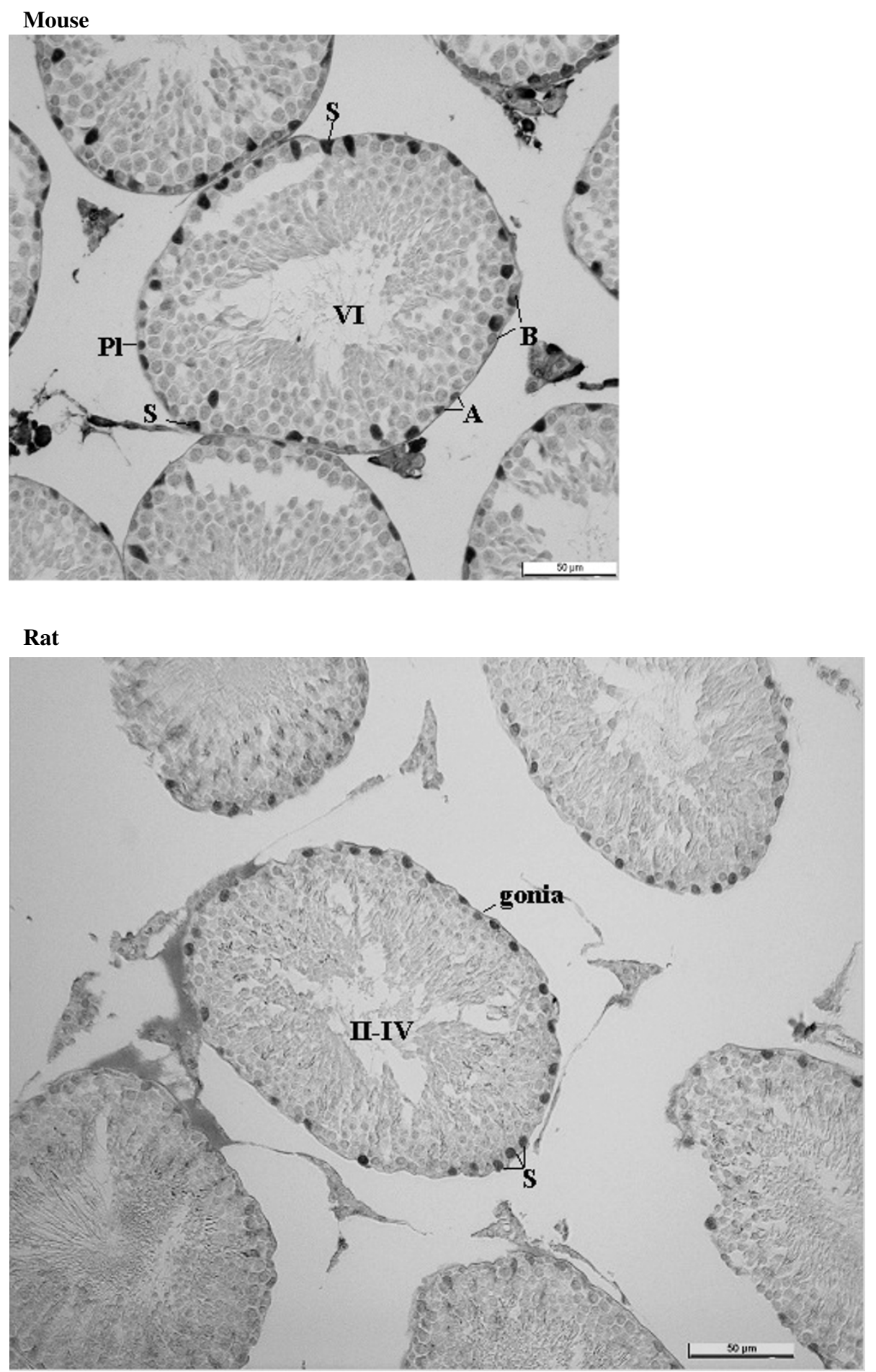

\section{Figure 5}

Immunohistochemical staining of sections from testis of mouse and rat with antibody against E2F-3. Labels are: for germline type A spermatogonia $(A)$, intermediate $(\mathrm{I})$ and $B$-type $(B)$ spermatogonia, preleptotene $(\mathrm{PI})$, pachythene $(\mathrm{P})$, zygotene $(\mathrm{Z})$, and diplotene (D)spermatocytes, spermatids (s), and for somatic Sertoli cell (S), Leydig cell (L), and peritubular myoid cell (M); stages indicated by Roman numerals I-XIV for rat and I-XII for mouse. 

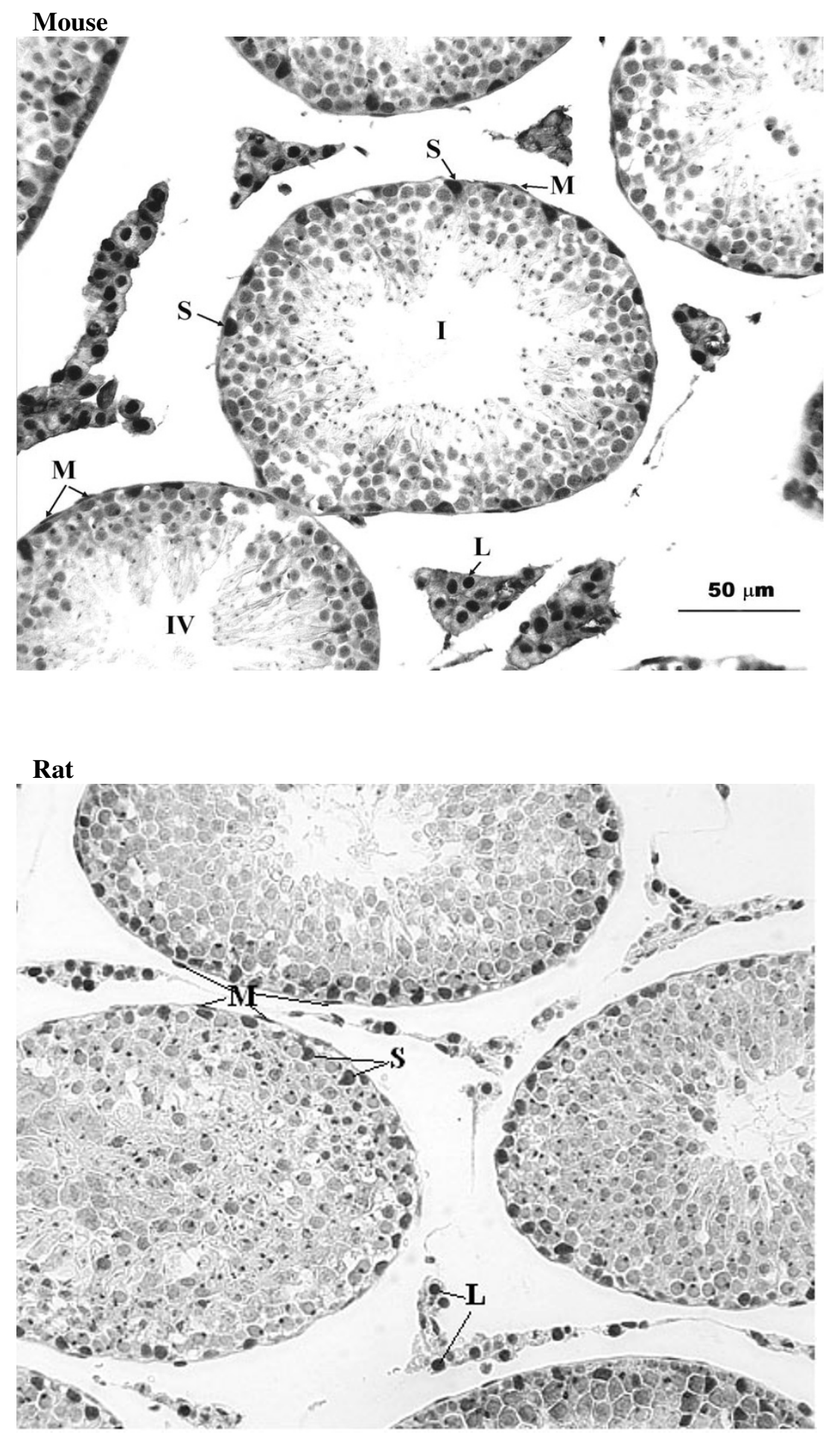

\section{Figure 6}

Immunohistochemical staining of sections from testis of mouse and rat with antibody against E2F-4. Labels are: for germline type A spermatogonia $(A)$, intermediate $(I)$ and $B$-type $(B)$ spermatogonia, preleptotene $(P I)$, pachythene $(P)$, zygotene $(Z)$, and diplotene (D)spermatocytes, spermatids (s), and for somatic Sertoli cell (S), Leydig cell (L), and peritubular myoid cell (M); stages indicated by Roman numerals I-XIV for rat and I-XII for mouse. 


\section{Rat}

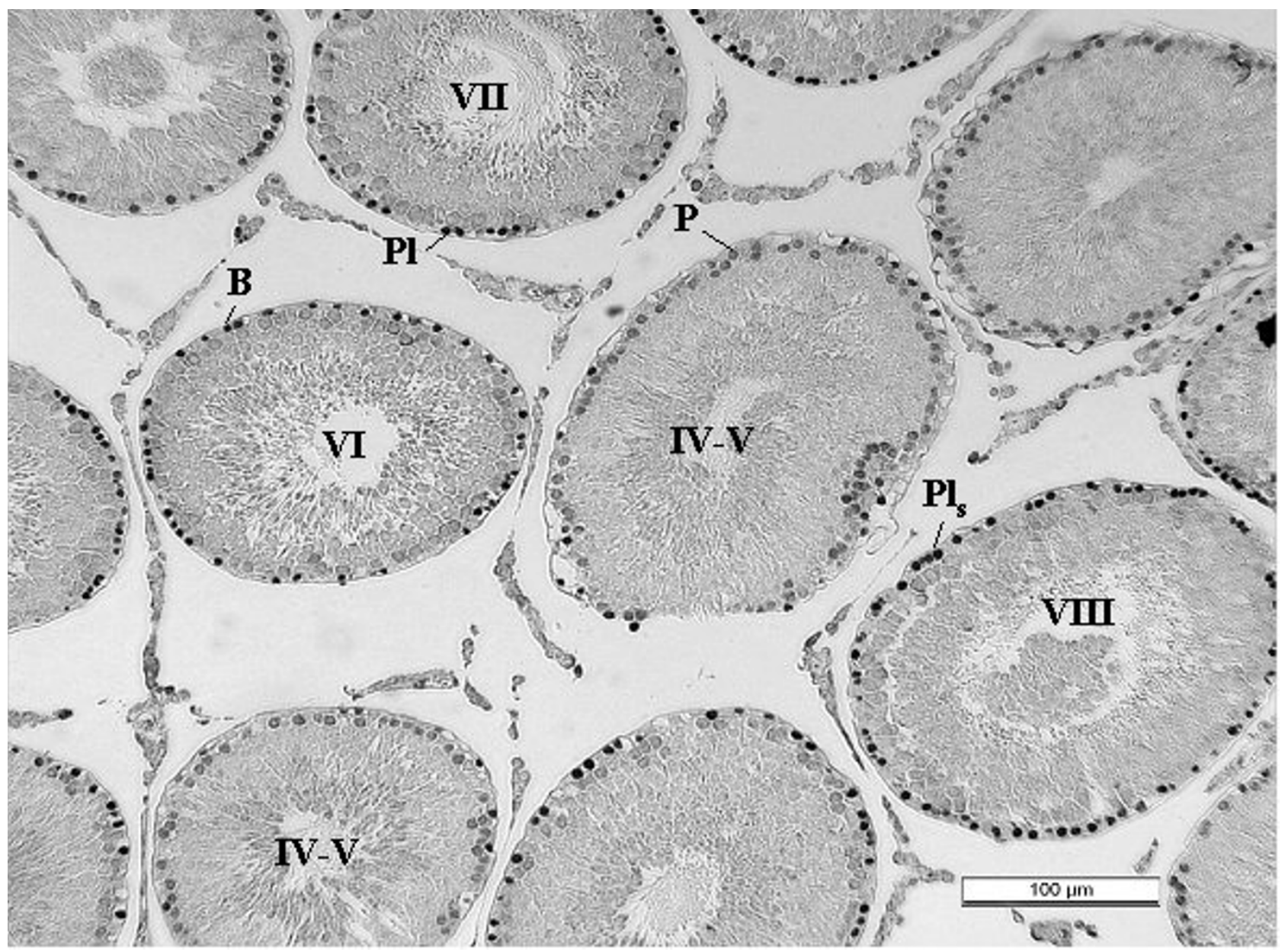

\section{Figure 7}

Immunohistochemical staining of section from testis of rat with antibody against E2F-5. Labels are: for germline type A spermatogonia $(A)$, intermediate $(\mathrm{I})$ and $B$-type $(B)$ spermatogonia, preleptotene $(\mathrm{PI})$, pachythene $(\mathrm{P})$, zygotene $(\mathrm{Z})$, and diplotene (D)spermatocytes, spermatids (s), and for somatic Sertoli cell (S), Leydig cell (L), and peritubular myoid cell (M); stages indicated by Roman numerals I-XIV for rat.

testis stained with antibody for detescting E2F-5 detected a protein about $65 \mathrm{kDa}$ band that peaked between stages II-III and IV-V just before the stageVI transition of the seminiferous epithelium (data not shown). Preliminary RTPCR results (not shown) for E2F-5 demonstrate its transcript level is constant throughout the cycle of the seminiferous epithelium.

\section{Discussion \\ E2F-I}

The detection of E2F-1 in early (type A) spermatogonial cells at stages II-V of rat testis but not mouse testis sections may be attributable to greater homology of the epitope (residues 342-386 of the human sequence) used to raise the KH-129 monoclonal antibody to the corresponding rat sequence. Anyway, very early type A spermatogonia, that might represent true spermatogonial stem cells (SSCs), are notoriously elusive to IHC staining. Still, the observation of Sertoli-cell-only tubules in E2F-1 -/- indicates that E2F-1 is likely expressed and activating gene programs required for proliferation in renewal as well as differentiation of SSCs. Other immunohistochemical studies conducted in our lab on sections from excised human testicular tumors have demonstrated that E2F-1 is strongly expressed in carcinoma in situ (data not submit- 


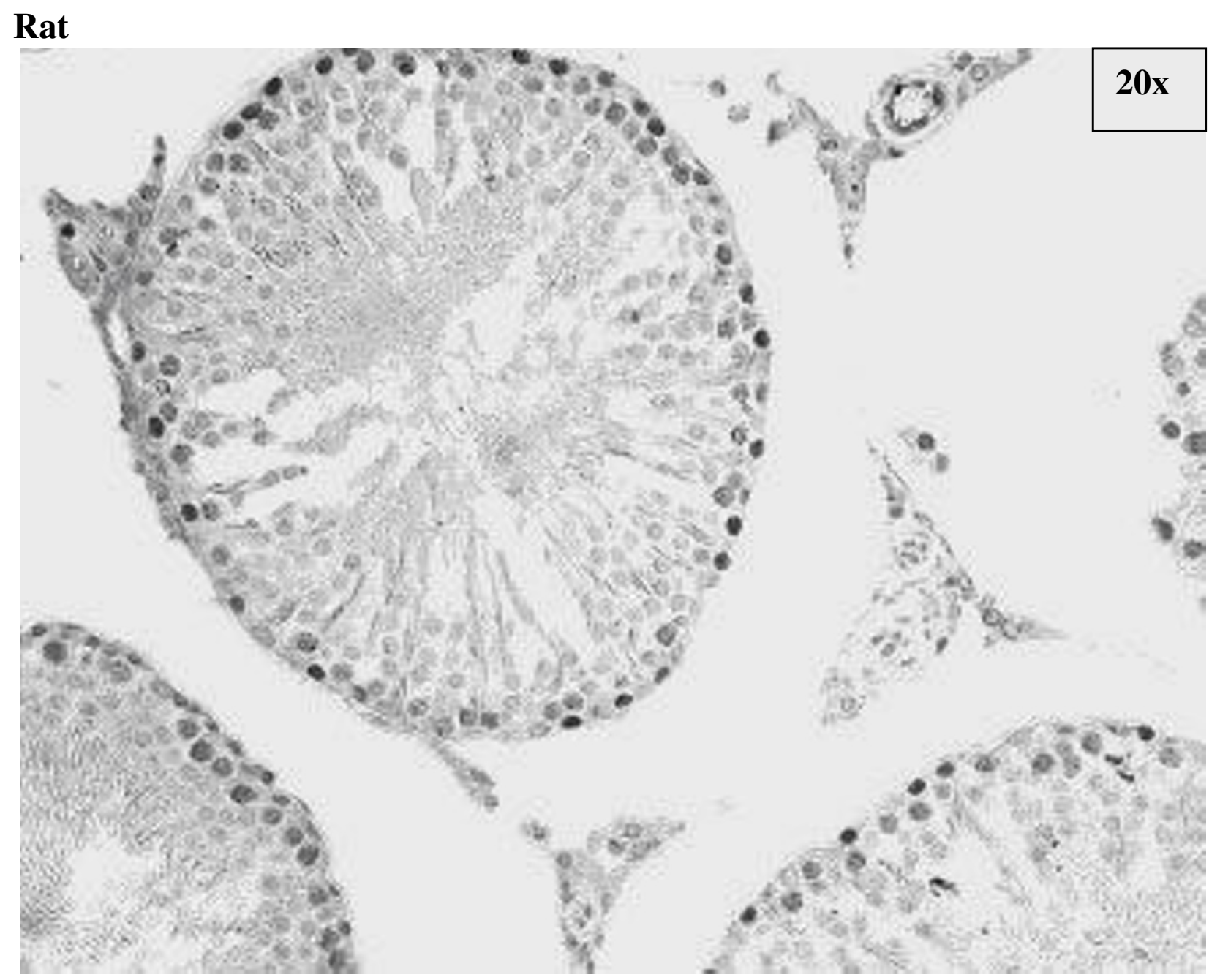

\section{Figure 8}

Immunohistochemical staining of section from testis of rat with antibody against pl07.

ted), supporting its role in initiating proliferation of SSCs in testis.

Staining of leptotene to early pachytene spermatocytes at stages IX to XI of wildtype mouse, and the conservation of such a staining pattern in the rat indicate that these cells are most likely to require E2F-1 regulated gene expression for the transition through prophase of meiosis I. It is conceivable that E2F-1 might also be responsible for activating the expression of pro-apoptosis genes in these cell types when stabilized by checkpoint proteins in the response to DNA double-strand breaks caused by genotoxic insult. In fact, apoptosis is mostly observed in the very cell types and stages in which we observe most E2F-1 in the testis. Such duality in the role of E2F-1 in the testis might explain why its level appears diminished in "runaway" seminomatous tumours of testis (data not submitted).

\section{E2F-2}

The observation of E2F-2 expression in cells wherein p107 had also been localized to a lesser extent (fig. 8), and wherein $\mathrm{pRb}$ was absent, is somewhat unexpected. However, others have observed that G1 CDKs can phosphorylate p107 to an extent which increases its binding to E2F1 at least transiently [24], though p107 otherwise displays a preference for binding E2F-4. Perhaps site-specific phosphorylation of p107 by cyclin A1 [25] or cyclin E2 [26] and cdk2 [27] enables it to interact with E2F-2 during meiosis. Alternatively, E2F-2 might be acting independently 


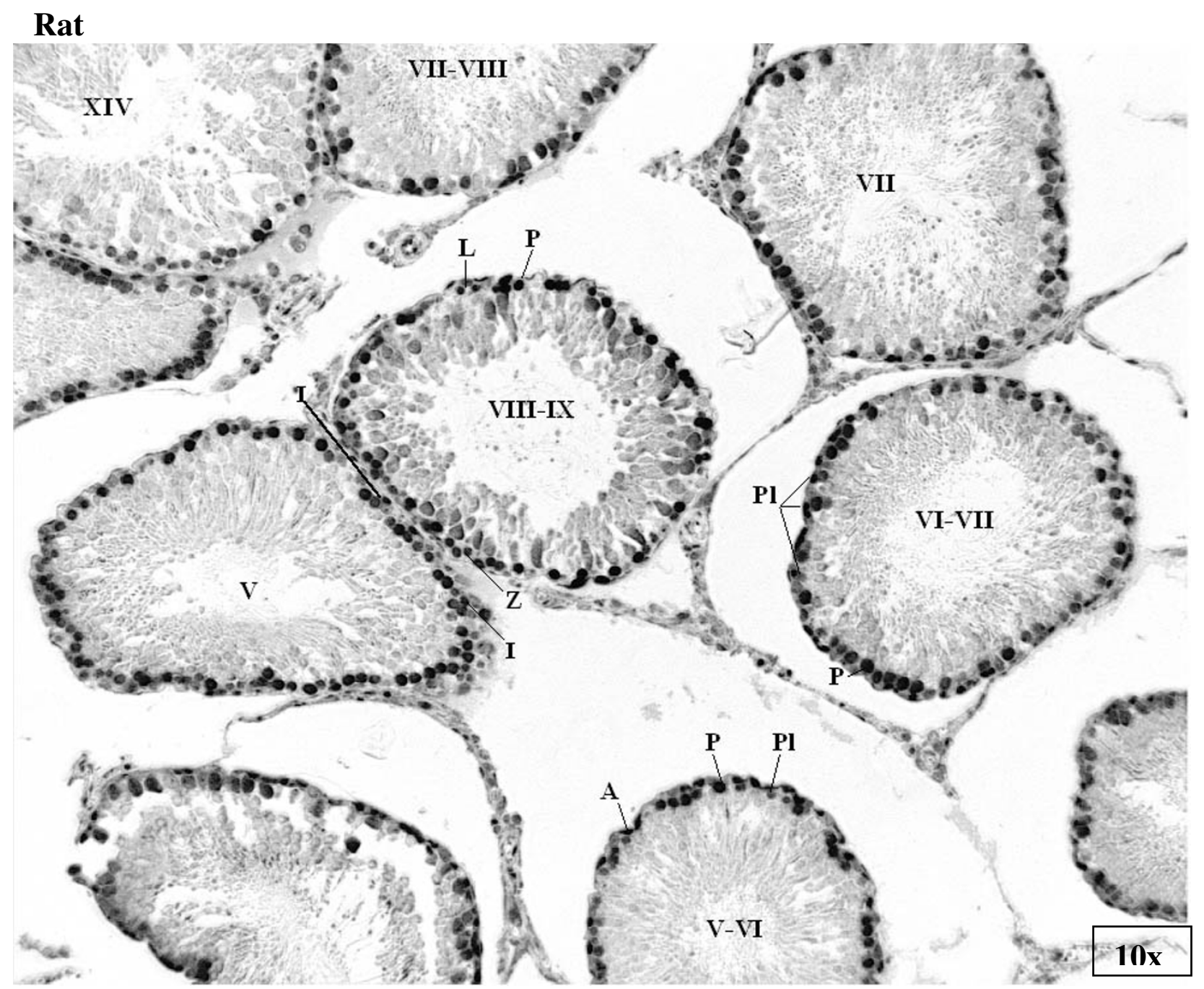

\section{Figure 9}

Immunohistochemical staining of section from testis of rat with antibody against SMADs I/2/3. Labels are: for germline type A spermatogonia (A), intermediate (I) and B-type (B) spermatogonia, preleptotene (PI), pachythene (P), zygotene (Z), and diplotene (D)spermatocytes, spermatids (s), and for somatic Sertoli cell (S), Leydig cell (L), and peritubular myoid cell (M); stages indicated by Roman numerals I-XIV for rat.

of p107 at these specific stages of spermatogenesis. Nevertheless, E2F-2 -/- mice were fertile [17] and no abnormal histology of testis was reported for the E2F-2 knockout or E2F-2/E2F-1 DKO mice. This indicates that another member of the E2F family might be able to compensate at this stage.

\section{E2F-3}

The prevalence of E2F-3 in spermatogonia of stages II to IV, and Sertoli cells of other stages, is especially noteworthy in light of the observation by others that E2F-1 -/- E2F$3+/$ - DKO mice display an accelerated atrophy in testis development compared to just E2F-1 -/- [12] However, staining of spermatogonia might also be explained by possible cross-reactivity of the monoclonal antibody used to detect E2F-3 for E2F-1. Compound E2F-1 -/- E2F-3 +/DKO males have severely atrophied testis and tubules already at 4 months (120 days) of age. The phenotype observed for the DKO indicates E2F-1 is indispensable for spermatogonial stem cell renewal. Our observation of E2F-3 in Sertoli cells might explain how a malfunction of Sertoli cells in the DKO could exacerbate the E2F-1 phenotype, since proper Sertoli cell function is necessary for normal maintenance of the testis. Combinatorial interac- 


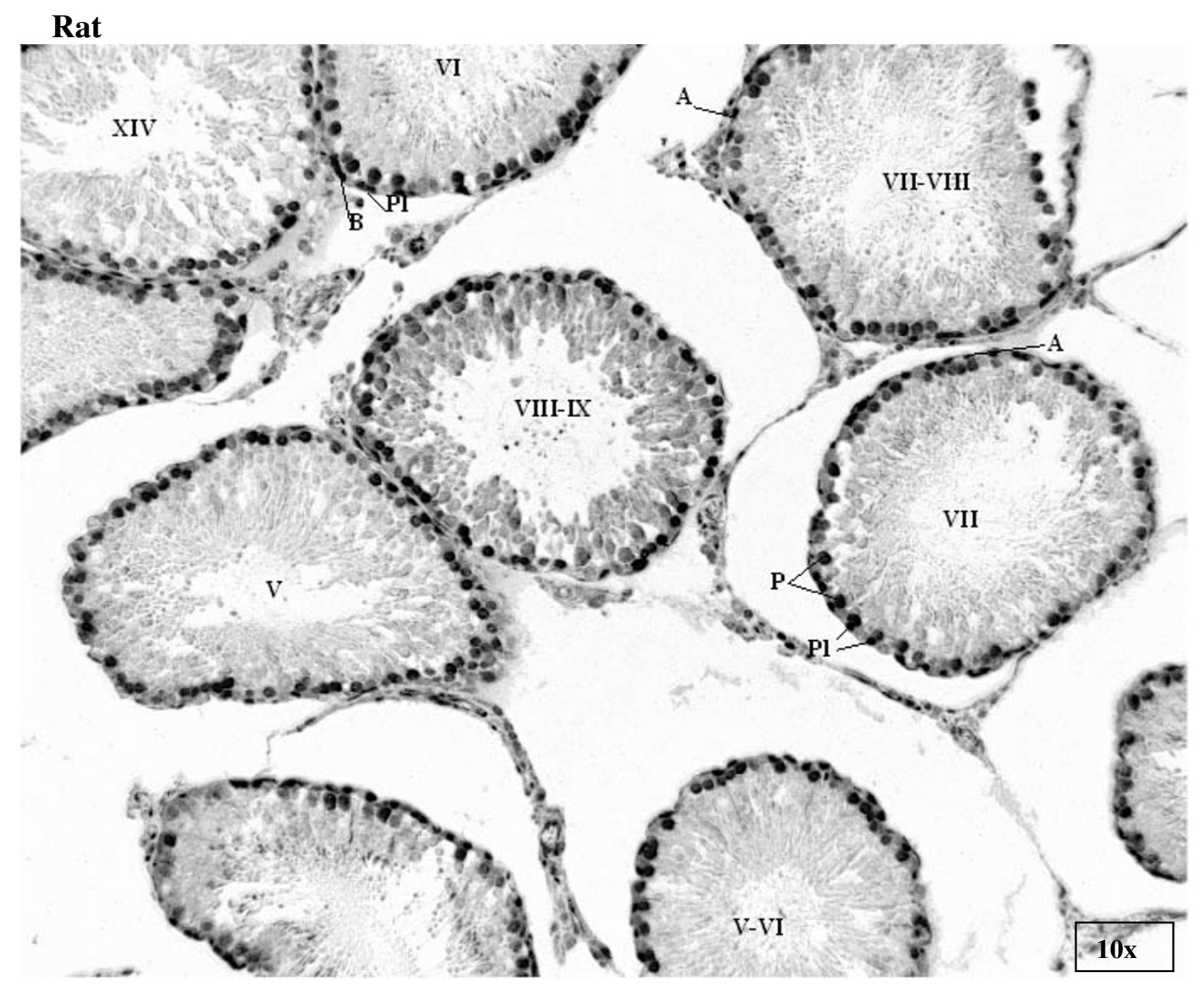

\section{Figure 10}

Immunohistochemical staining of section from testis of rat with antibody against SMAD 4. Labels are: for germline type A spermatogonia $(A)$, intermediate $(\mathrm{I})$ and $B$-type $(B)$ spermatogonia, preleptotene $(\mathrm{PI})$, pachythene $(\mathrm{P})$, zygotene $(\mathrm{Z})$, and diplotene (D)spermatocytes, spermatids (s), and for somatic Sertoli cell (S), Leydig cell (L), and peritubular myoid cell (M); stages indicated by Roman numerals I-XIV for rat.

tions between the functionalities of E2F-1 and E2F-3 have been recently characterized [28].

\section{E2F-4}

The localization of E2F-4 to the same somatic cell compartment, the Sertoli cells, as p130 was previously mapped to agrees with the paradigm of its role in maintaining terminally differentiated states by repressing the expression of genes expressed in cycling cells. Furthermore, the increasing level of E2F-4 protein detected from stages VII on could relate to the testosterone sensitivity of
Sertoli cells during this period of the seminiferous epithelial cycle.

\section{E2F-5}

This localization of E2F-5 resembles that of p107 (Fig. 8), which was determined from earlier studies (Fig. 18) to be expressed throughout meiosis. Furthermore, when compared to the staining of young primary spermatocytes with antibodies against the SMADs (Figures 9 and 10), it is possible to envision how E2F-5 might interact with p107, activated SMADS 2/3 and SMAD 4 to be tranlocated 


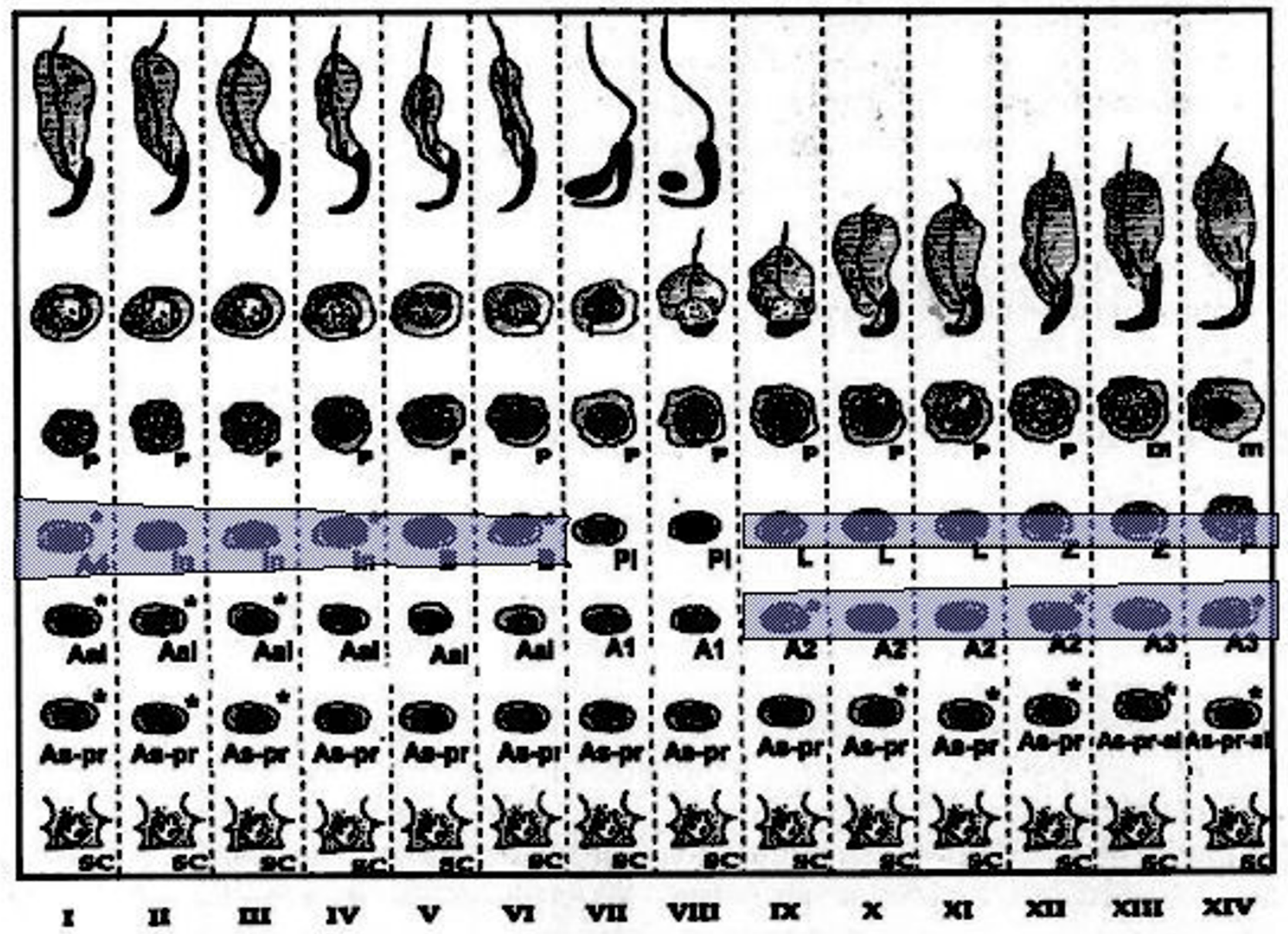

Figure I I

Chart of immunohistochemical staining of E2F-I, in cells and stages of rat seminiferous tubule cycle. The width of shading indicates intensity of staining. Abbreviations: As = spermatogonial stem cell, As-pr = paired spermatogonia, As-pr-al = paired and aligned spermatogonia, Aal- $n=$ aligned spermatogonia of $n$ number of cells, $A n=$ differentiated type $A$ spermatogonia entering synchronised division number $\mathrm{n}$, In = intermediate type spermatogonia, $\mathrm{B}=\mathrm{B}$-type spermatogonia which undergo final mitotic division before replication and division for Meiosis I, PI = preleptotene, $\mathrm{L}=$ leptotene, $\mathrm{Z}=$ zygotene, $\mathrm{P}=\mathrm{pachythene}, \mathrm{m}=\mathrm{mei}-$ osis, $\mathrm{In}=$ intermediate, and $\mathrm{Sc}=$ Sertoli cell.

to the nucleus [29] in leptotene, zygotene and early pachytene spermatocytes of stages VI to XIV. Such a tripartite complex interaction has been recently demonstrated for TGF-beta mediated repression of replication of cells in culture [30]. However, the IHC of rat testis displaying a localization of E2F-5 distinct from that of E2F-4 and overlapping those of E2F-1 and E2F-2 might also be explained by a possibility of cross-reactivity of the monoclonal antibody used to detect E2F-5 with the E2F-1 and E2F-2 of rat, since we were not able to detect any significant signals from staining of mouse testis sections.

\section{Distinct localizations of E2F-I and E2F-4}

This observation fits nicely with the scheme of spermatogonial development presented in Figure 1, since E2F-1 is considered a key transcription factor capable of transactivating the expression of numerous proteins required for DNA replication and the transition to $S$ phase of the cell cycle in actively proliferating cells. E2F-1 is also somewhat unique in its dual capacity to transactivate the expression of pro-apoptotic genes in response to DNA-damage-activated checkpoints at the S/G2 transition, and perhaps this dualism in E2F-1's roles is related to the observation that 


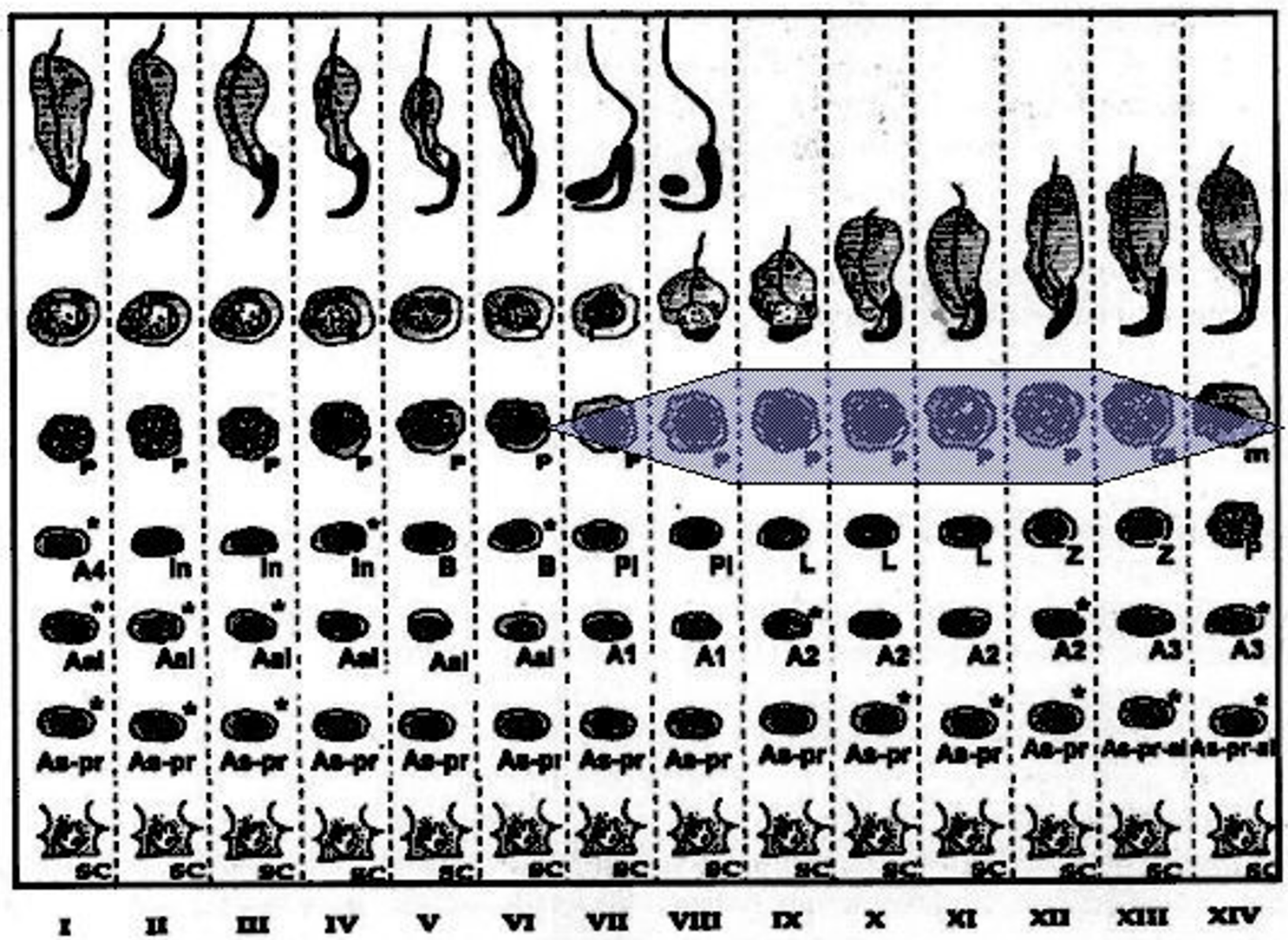

Figure 12

Chart of immunohistochemical staining of E2F-2, in cells and stages of rat seminiferous tubule cycle. The width of shading indicates intensity of staining. Abbreviations: As = spermatogonial stem cell, As-pr = paired spermatogonia, As-pr-al = paired and aligned spermatogonia, Aal- $n=$ aligned spermatogonia of $n$ number of cells, $A n=$ differentiated type $A$ spermatogonia entering synchronised division number $\mathrm{n}$, In = intermediate type spermatogonia, $\mathrm{B}=\mathrm{B}$-type spermatogonia which undergo final mitotic division before replication and division for Meiosis I, PI = preleptotene, $\mathrm{L}=$ leptotene, $\mathrm{Z}=$ zygotene, $\mathrm{P}=\mathrm{pachythene}, \mathrm{m}=\mathrm{mei}-$ osis, $\ln =$ intermediate, and $\mathrm{Sc}=$ Sertoli cell.

apoptosis of spermatogonia coincides (Fig. 1) with the stages of peak E2F-1 levels. In contrast, E2F-5 might be expected to repress the expression of S phase genes [31], while phosphorylated E2F-5 could function as a coactivator and autoregulator of late G1 and S phase genes as observed by others [32], perhaps transactivating the expression of the meiosis-specific Cyclin E2 or Cyclin A, and possibly other genes required for meiosis and differentiation $[16,33]$.

\section{Conclusion}

The observations described above indicate a scenario (Fig. 18) wherein E2F-1 is expressed in very young type A spermatogonial (stem) cells, suggesting that E2F-1 is a key transcription factor in activating the expression of genes necessary for entering the proliferative phase of spermatogenesis. This might follow p130 phosphorylation and inactivation in response to paracrine GDNF secretion from Sertoli cells stimulated by the endocrine gonadotropin FSH. It is quite possible that pRb levels increase at this point in order to maintain a check on E2F-1 and its proapoptotic activities. That E2F-1, E2F-5 and E2F-2 are the principle members of the E2F family present in germ cells during meiosis, alongside our previous observation that the only member of the retinoblastoma protein family to be expressed throughout this period is p107 suggests that these three E2Fs are interacting with p107 in order to target its repressive role to specific genes. Otherwise, they 


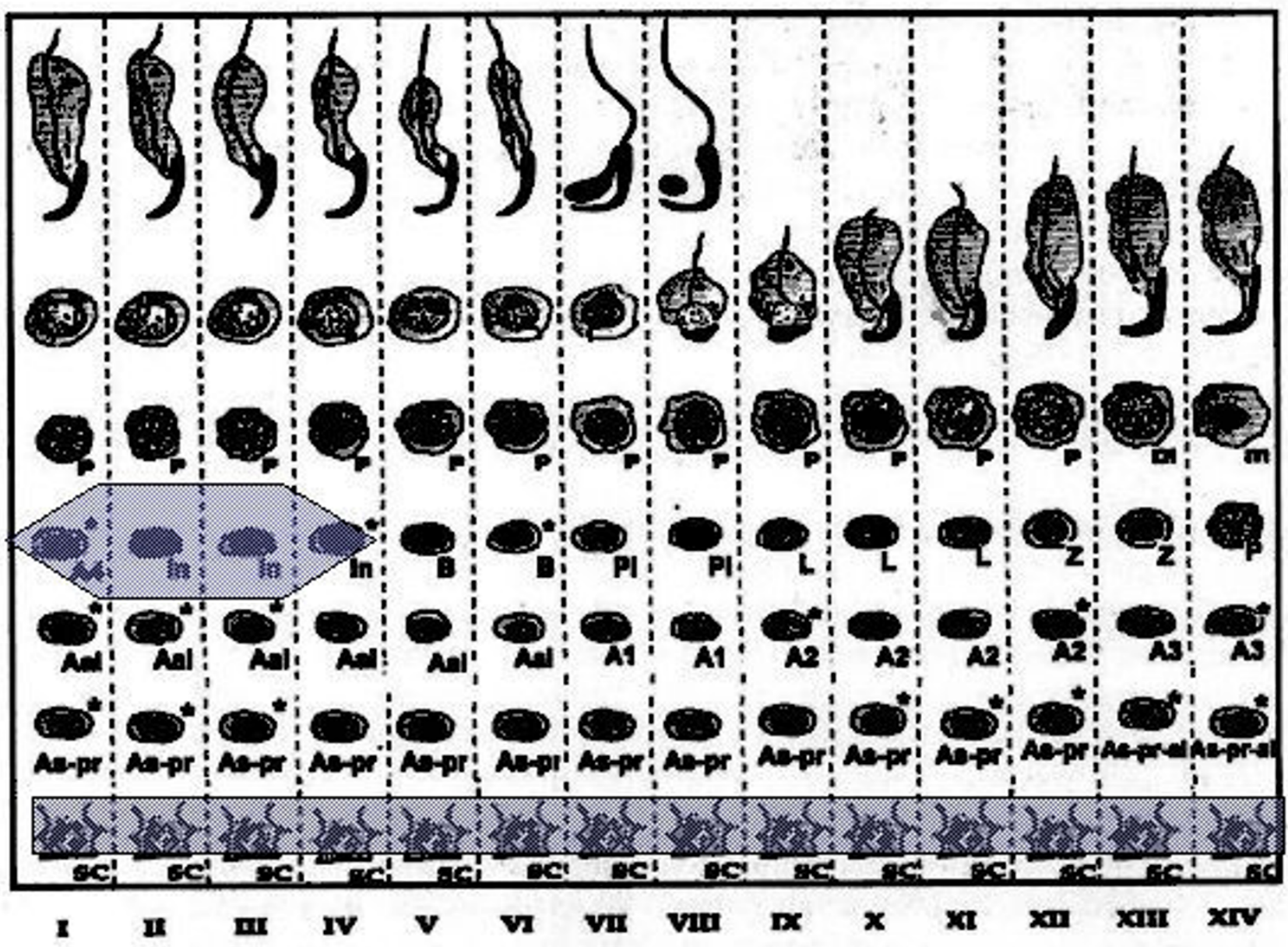

Figure 13

Chart of immunohistochemical staining of E2F-3, in cells and stages of rat seminiferous tubule cycle. The width of shading indicates intensity of staining. Abbreviations: As = spermatogonial stem cell, As-pr = paired spermatogonia, As-pr-al = paired and aligned spermatogonia, Aal- $n=$ aligned spermatogonia of $n$ number of cells, $A n=$ differentiated type $A$ spermatogonia entering synchronised division number $\mathrm{n}$, In $=$ intermediate type spermatogonia, $\mathrm{B}=\mathrm{B}$-type spermatogonia which undergo final mitotic division before replication and division for Meiosis I, PI = preleptotene, $\mathrm{L}=$ leptotene, $\mathrm{Z}=$ zygotene, $\mathrm{P}=$ pachythene, $\mathrm{m}=$ meiosis, $\mathrm{In}=$ intermediate, and $\mathrm{Sc}=$ Sertoli cell.

could be acting independently of a retinoblastoma protein in regulating the expression of different sets of genes at different stages of the extended prophase of meiosis. E2F-3 appears to be serving dual roles in Sertoli cells and late spermatogonia, most likely under the hormoneresponsive control of $\mathrm{pRb}$. This later observation presents the tantalizing prospect that E2F-3 might actually be interacting with the androgen receptor (AR) of Sertoli cells via its $\mathrm{Rb}$ partner, since it has been previously demonstrated by others that $\mathrm{pRb}$ can serve a coactivator role in complexes with AR. In germ cells, E2F-3 appears to be filling in a gap between E2F-1 and E2F-5 at the intermediate stage between type A and type B spermatogonia, possibly activating the expression of genes required for commitment to the differentiative pathway, following inactivation of $\mathrm{pRb}$ in response to the SCF ligand. In Sertoli cells, E2F-3 is most likely checked by pRb, but then released and activating the expression of genes in a signal transduction cascade response to stimulation by gonadotropins and testosterone. It is conceivable that there is an overlap of target genes controlled by E2F-3 and E2F-4 in Sertoli cells. This could be resolved at least in part by ongoing chromatin immunoprecipitation for genomic microarray (ChIPon-chip) studies to ascertain the target genes of E2Fs expressed in testis. Another key question is the identity of 


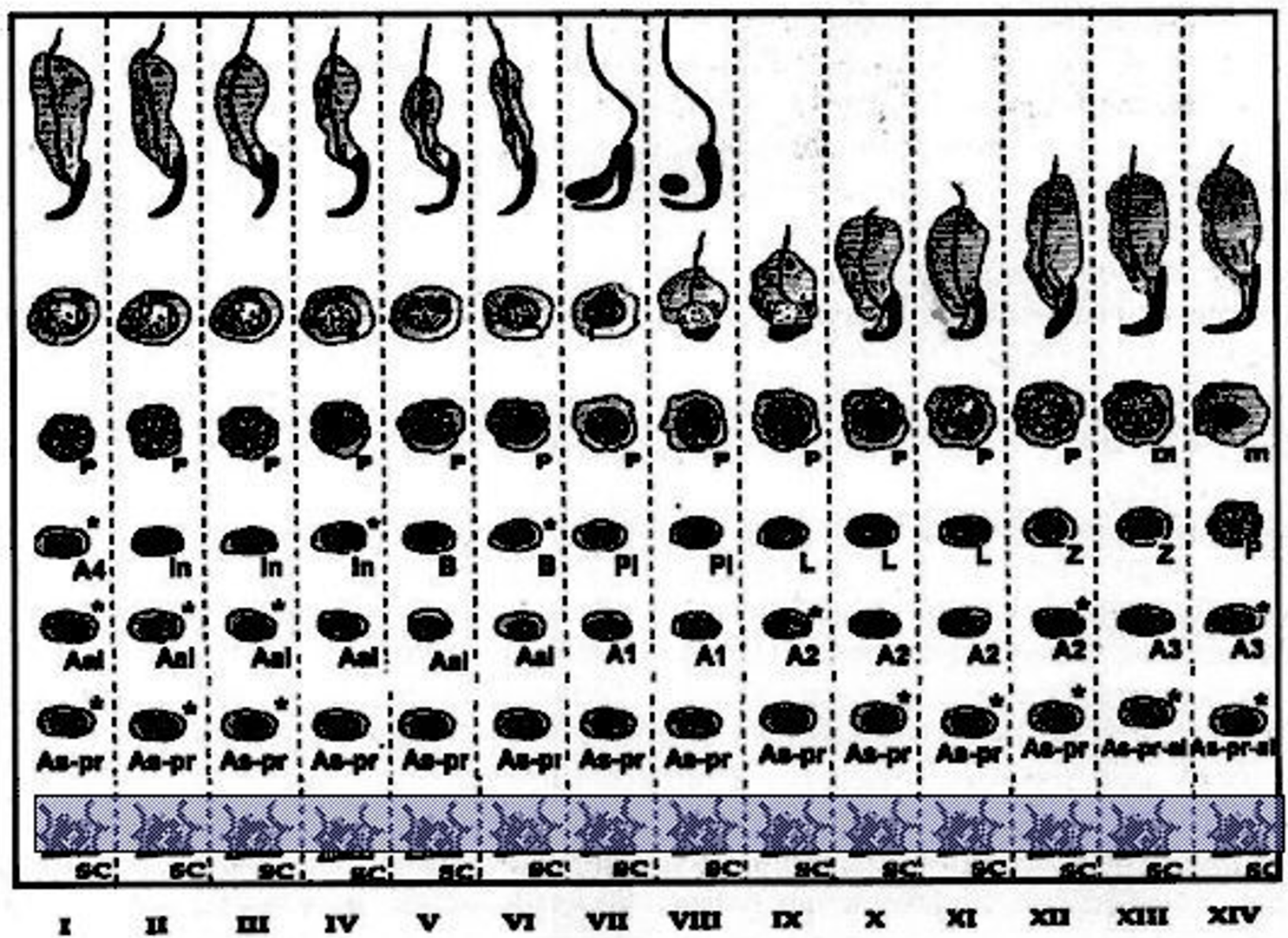

Figure 14

Chart of immunohistochemical staining of E2F-4, in cells and stages of rat seminiferous tubule cycle. The width of shading indicates intensity of staining. Abbreviations: As = spermatogonial stem cell, As-pr = paired spermatogonia, As-pr-al = paired and aligned spermatogonia, Aal- $n=$ aligned spermatogonia of $n$ number of cells, $A n=$ differentiated type $A$ spermatogonia entering synchronised division number $\mathrm{n}$, In = intermediate type spermatogonia, $\mathrm{B}=\mathrm{B}$-type spermatogonia which undergo final mitotic division before replication and division for Meiosis I, PI = preleptotene, $\mathrm{L}=$ leptotene, $\mathrm{Z}=$ zygotene, $\mathrm{P}=\mathrm{pachythene}, \mathrm{m}=\mathrm{mei}-$ osis, $\mathrm{In}=$ intermediate, and Sc = Sertoli cell.

the E2F that interacts with p130 in quiescent spermatogonial stem cells.

\section{Competing interests}

The author(s) declare that they have no competing interests.

\section{Authors' contributions}

KED designed the study, performed all the experiments, and wrote and revised all drafts of the manuscript. MP helped with microdissection, and provided comments to results and drafts of the manuscript. JT provided background information on testis biology, guidance in microdissection, helped with data analysis, and reviewed drafts of the manuscript. All authors read and approved the final manuscript.

\section{Acknowledgements}

We are grateful to Janne Suominen for help with microdissection and protein extraction protocols, Patrick Humbert for the protocol for genotyping E2F-4 and E2F-5 knockout mice and for recommendation of antibodies for Western blot and immunohistochemical analyses of samples from E2F-4 mice, Jacqueline Lees and Paul Danielen for a monoclonal antibody and immunostaining conditions used to confirm E2F-4 on Western blots, Noora Kotaja for help with optimizing immunostaining conditions used for detecting E2F-I on Western blots, and Heikki Hiekkanen for help with the statistical analysis. This work was supported by grants from the EU Quality of Life Programme (QLK4-2002-), the Academy of Finland, the Sigrid Juselius Foundation, and Turku University Central Hospital to JT. 


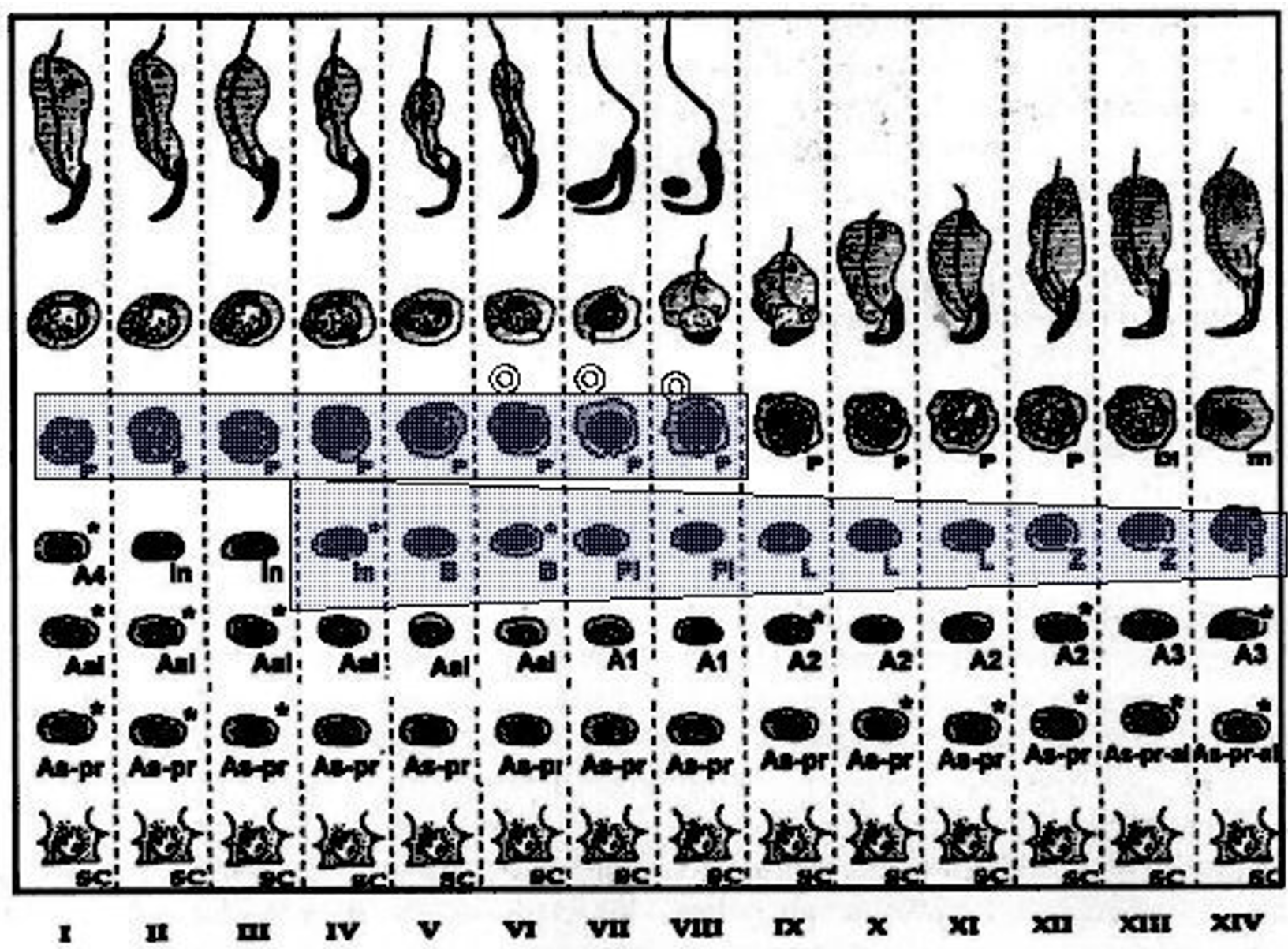

Figure 15

Chart of immunohistochemical staining of E2F-5, in cells and stages of rat seminiferous tubule cycle. The width of shading indicates intensity of staining. Abbreviations: As = spermatogonial stem cell, As-pr = paired spermatogonia, As-pr-al = paired and aligned spermatogonia, Aal-n = aligned spermatogonia of $n$ number of cells, $A n=$ differentiated type $A$ spermatogonia entering synchronised division number $n, \ln =$ intermediate type spermatogonia, $B=B$-type spermatogonia which undergo final mitotic division before replication and division for Meiosis I, $\mathrm{PI}=$ preleptotene, $\mathrm{L}=$ leptotene, $\mathrm{Z}=$ zygotene, $\mathrm{P}=$ pachythene, $\mathrm{m}=$ meiosis, $\mathrm{In}=$ intermediate, and $\mathrm{Sc}=$ Sertoli cell. 

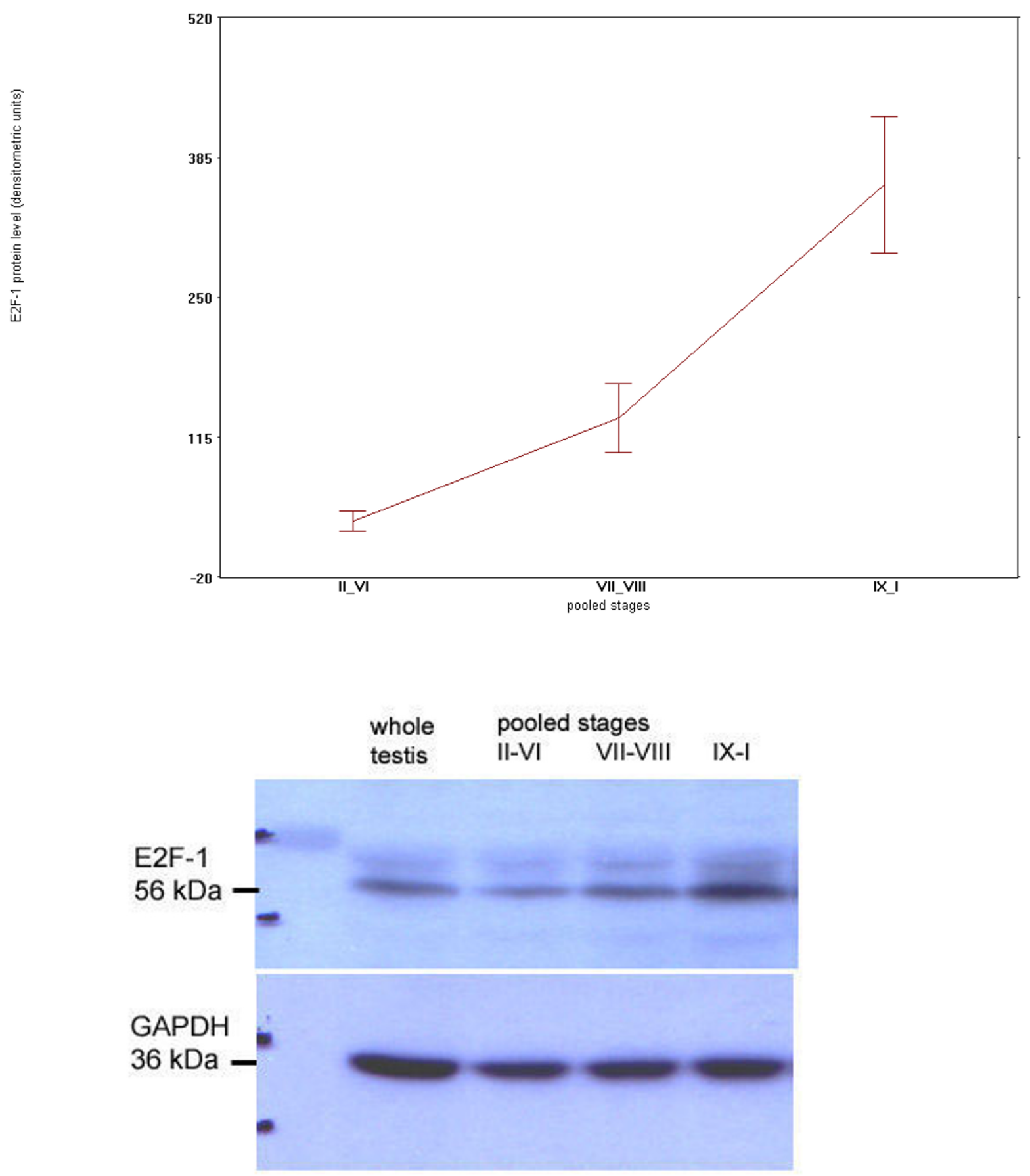

Figure 16

Plot of specific protein level, and immunostained Western blot representative of four different sets, for E2F-I, and GAPDH, in total proteins extracted from three pooled stages of mouse. 
Level of E2F-4 protein for three pooled stages of mouse seminiferous tubules
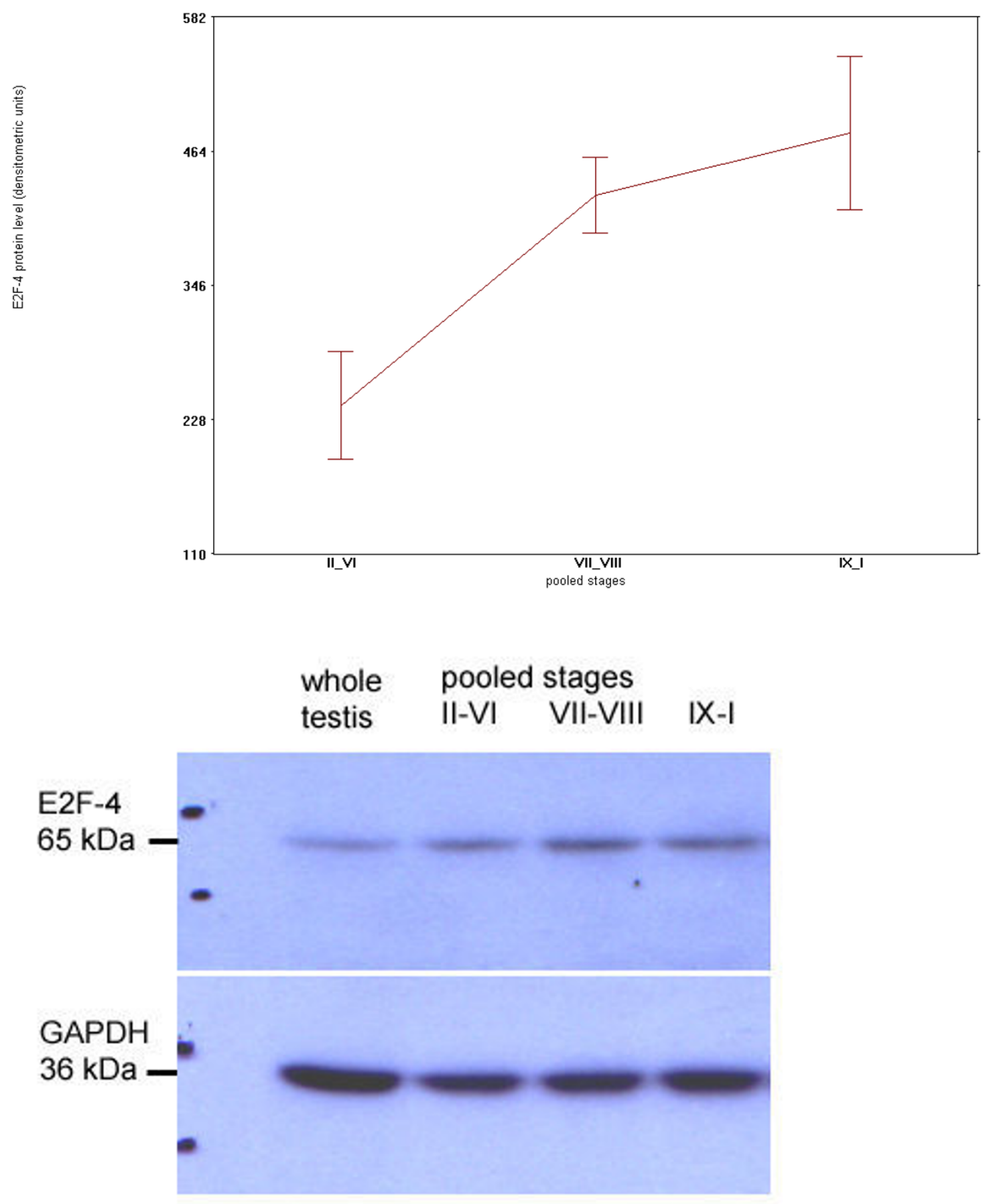

Figure 17

Plot of specific protein level, and immunostained Western blot representative of four different sets, for E2F-4, and GAPDH, in total proteins extracted from three pooled stages of mouse. 


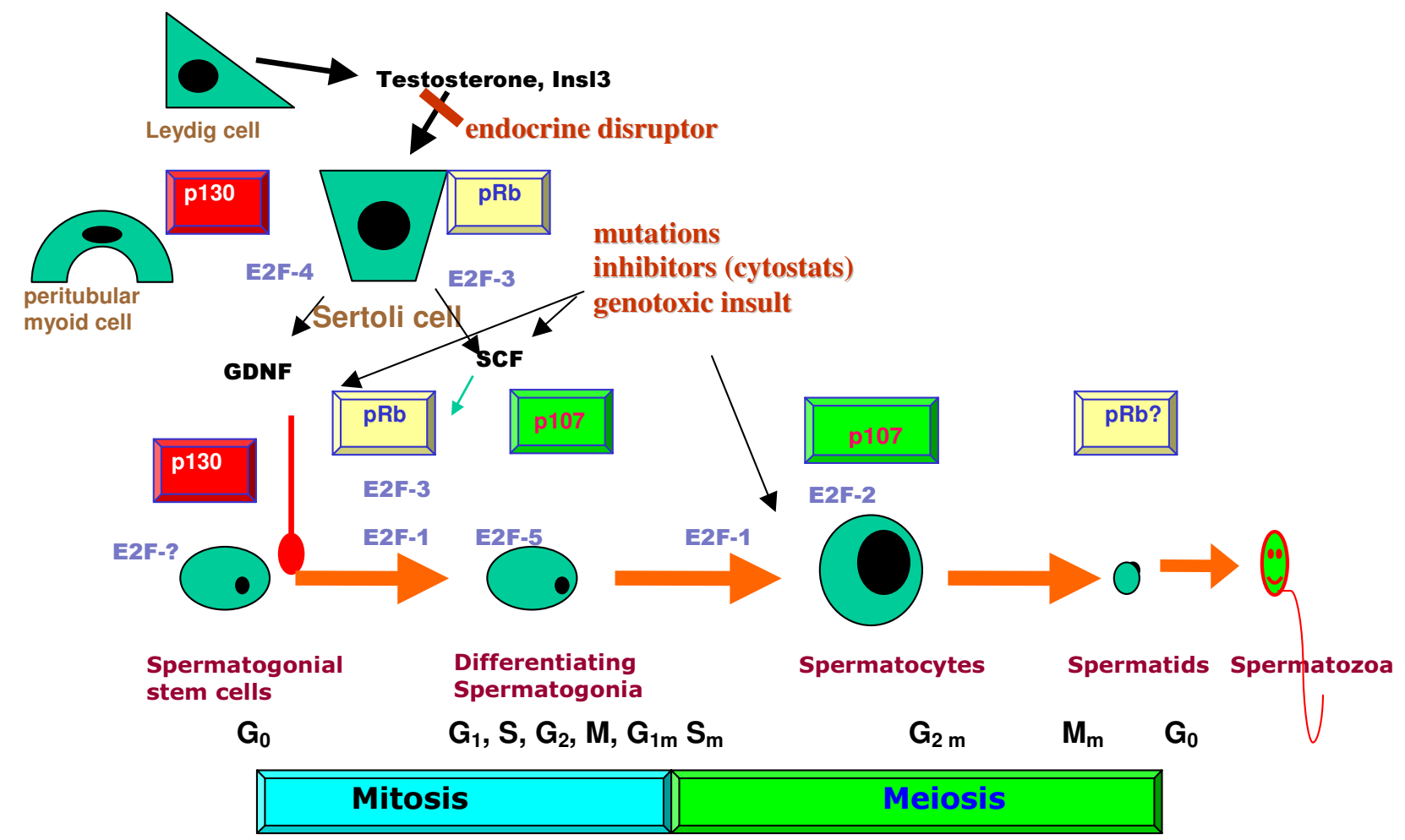

Figure 18

Diagram summarizing differential expression of members of the retinoblastoma proteins [9, I0] and their E2F partners in testis, and showing how endocrine signals and other factors could influence testis development via interactions between these two families of cell cycle regulators.

\section{References}

I. de Rooij DG: Proliferation and differentiation of spermatogonial stem cells. Reproduction 200I, I $21: 347-354$.

2. Zhao GQ, Garbers DL: Male germ cell specification and differentiation. Dev Cell 2002, 2:537-547.

3. Brinster RL: Germline stem cell transplantation and transgenesis. Science 2002, 296:2174-2176.

4. Rey R: Regulation of spermatogenesis. In The Developing Testis. Physiology and Pathophysiology Volume 5. Edited by: Söder O. Basel: Karger; 2003:38-55. [Savage MO (Series Editor): Endocrine Development]

5. Morris EJ, Dyson NJ: Retinoblastoma protein partners. In Advances in Cancer Research Volume 82. Edited by: Vande Woude G. Oxford: Elsevier; 200 I: I-54.

6. Dyson N: The regulation of E2F by pRB-family proteins. Genes Dev 1998, I 2:2245-2262.

7. Sicinski P, Donaher JL, Geng Y, Parker SB, Gardner H, Park MY, Robker RL, Richards JS, McGinnis LK, Biggers JD, Eppig J], Bronson RT, Elledge SJ, Weinberg RA: Cyclin D2 is an FSH-responsive gene involved in gonadal cell proliferation and oncogenesis. Nature 1996, 384:470-474

8. Feng LX, Ravindranath N, Dym M: Stem cell factor/c-kit up-regulates cyclin D3 and promotes cell cycle progression via the phosphoinositide 3-kinase/p70 S6 kinase pathway in spermatogonia. J Biol Chem 2000, 275:25572-25576.

9. Yan W, Kero J, Suominen J, Toppari J: Differential expression and regulation of the retinoblastoma family of proteins during testicular development and spermatogenesis: roles in the control of germ cell proliferation, differentiation and apoptosis. Oncogene 200I, 20:1343-1356.
10. Toppari J, Suominen JS, Yan W: The role of retinoblastoma protein family in the control of germ cell proliferation, differentiation and survival. APMIS 2003, I I I:245-5I.

11. Yamasaki L, Jacks T, Bronson R, Goillot E, Harlow E, Dyson NJ: Tumor induction and tissue atrophy in mice lacking E2F-I. Cell 1996, 85:537-548.

12. Cloud JE, Rogers C, Reza TL, Ziebold U, Stone JR, Picard MH, Caron AM, Bronson RT, Lees JA: Mutant mouse models reveal the relative roles of E2FI and E2F3 in vivo. Mol Cell Biol 2002, 22:2663-2672.

13. Storre J, Elsasser HP, Fuchs M, Ullmann D, Livingston DM, Gaubatz S: Homeotic transformations of the axial skeleton that accompany a targeted deletion of E2f6. EMBO Rep 2002, 3:695-700.

14. Humbert PO, Rogers C, Ganiatsas S, Landsberg RL, Trimarchi JM, Dandapani S, Brugnara C, Erdman S, Schrenzel M, Bronson RT, Lees JA: E2F4 is essential for normal erythrocyte maturation and neonatal viability. Mol Cell 2000, 6:28I-29I.

15. Rempel RE, Saenz-Robles MT, Storms R, Morham S, Ishida S, Engel A Jakoi L, Melhem MF, Pipas JM, Smith C, Nevins JR: Loss of E2F4 activity leads to abnormal development of multiple cellular lineages. Mol Cell 2000, 6:293-306.

16. Lindeman GJ, Dagnino L, Gaubatz S, Xu Y, Bronson RT, Warren HB, Livingston DM: A specific, nonproliferative role for E2F-5 in choroid plexus function revealed by gene targeting. Genes Dev 1998, 12:1092-1098.

17. Murga M, Fernandez-Capetillo O, Field SJ, Moreno B, Borlado LR, Fujiwara Y, Balomenos D, Vicario A, Carrera AC, Orkin SH, Greenberg ME, Zubiaga AM: Mutation of E2F2 in mice causes enhanced T lymphocyte proliferation, leading to the development of autoimmunity. Immunity 200I, 15:959-970. 
18. Field SJ, Tsai FY, Kuo F, Zubiaga AM, Kaelin WG, Livingston DM, Orkin SH, Greenberg ME: E2F-I functions in mice to promote apoptosis and suppress proliferation. Cell 1996, 85:549-56I.

19. Yan W, Suominen J, Samson M, Jegou B, Toppari J: Involvement of Bcl-2 family proteins in germ cell apoptosis during testicular development in the rat and pro-survival effect of stem cell factor on germ cells in vitro. Mol Cell Endocrinol 2000, 165:115-129.

20. Shi SR, Key ME, Kalra KL: Antigen retrieval in formalin-fixed, paraffin-embedded tissues: an enhancement method for immunohistochemical staining based on microwave oven heating of tissue sections. I Histochem Cytochem 1991, 39:74I-748.

21. Pulford K, Delsol G, Roncador G, Biddolph S, Jones M, Mason DY: Immunohistochemical screening for oncogenic tyrosine kinase activation. J Pathol 1999, 187:588-593.

22. Parvinen M, Toppari J, Lahdetie J: Transillumination phase contrast microscopic techniques for evaluation of male germ cell toxicity and mutagenicity. In Methods in Reproductive Toxicology Edited by: Chapin RE, Heindel J. Orlando: Academic Press; 1993:142-165.

23. Towbin H, Staehelin T, Gordon J: Electrophoretic transfer of proteins from polyacrylamide gels to nitrocellulose sheets: procedure and some applications. Proc Natl Acad Sci USA 1979, 76:4350-4354.

24. Calbo J, Parreno M, Sotillo E, Yong T, Mazo A, Garriga J, Grana X: G I cyclin/cyclin-dependent kinase-coordinated phosphorylation of endogenous pocket proteins differentially regulates their interactions with E2F4 and E2FI and gene expression. J Biol Chem 2002, 277:50263-50274.

25. Wolgemuth DJ, Lele KM, Jobanputra V, Salazar G: The A-type cyclins and the meiotic cell cycle in mammalian male germ cells. Int J Androl 2004, 27:192-199.

26. Geng Y, Yu Q, Sicinska E, Das M, Schneider JE, Bhattacharya S, Rideout WM, Bronson RT, Gardner H, Sicinski P: Cyclin E ablation in the mouse. Cell 2003, I 1 4:43 I-443.

27. Ortega S, Prieto I, Odajima J, Martin A, Dubus P, Sotillo R, Barbero $\mathrm{JL}$, Malumbres M, Barbacid M: Cyclin-dependent kinase 2 is essential for meiosis but not for mitotic cell division in mice. Nat Genet 2003, 35:25-3I.

28. Giangrande PH, Zhu W, Rempel RE, Laakso N, Nevins JR: Combinatorial gene control involving E2F and E Box family members. $E M B O$ J 2004, 23: 1336-1347.

29. Derynck R, Zhang YE: Smad-dependent and Smad-independent pathways in TGF-beta family signaling. Nature 2003 425:577-584.

30. Chen CR, Kang Y, Siegel PM, Massague J: E2F4/5 and p 107 as Smad cofactors linking the TGFbeta receptor to c-myc repression. Cell 2002, I 1 0:19-32.

31. Takahashi Y, Rayman JB, Dynlacht BD: Analysis of promoter binding by the $E 2 F$ and $p R B$ families in vivo: distinct $E 2 F$ proteins mediate activation and repression. Genes Dev 2000, | 4:804-8|6.

32. Morris L, Allen KE, La Thangue NB: Regulation of E2F transcription by cyclin E-Cdk2 kinase mediated through p300/CBP coactivators. Nat Cell Biol 2000, 2:232-239.

33. Ruiz S, Segrelles C, Bravo A, Santos M, Perez P, Leis H, Jorcano JL, Paramio JM: Abnormal epidermal differentiation and impaired epithelial-mesenchymal tissue interactions in mice lacking the retinoblastoma relatives pl07 and pl30. Development 2003, I 30:234I-2353.
Publish with Bio Med Central and every scientist can read your work free of charge

"BioMed Central will be the most significant development for disseminating the results of biomedical research in our lifetime. "

Sir Paul Nurse, Cancer Research UK

Your research papers will be:

- available free of charge to the entire biomedical community

- peer reviewed and published immediately upon acceptance

- cited in PubMed and archived on PubMed Central

- yours - you keep the copyright

Submit your manuscript here:

http://www.biomedcentral.com/info/publishing_adv.asp
BiolMedcentral 